\title{
PERGERAKAN BERSAMA MATA UANG ASEAN 4 PERIODE 1997-2005: SUATU APLIKASI TEORI OPTIMAL CURRENCY AREA DENGAN MENGGUNAKAN MODEL VECTOR ERROR CORRECTION
}

\author{
Moch. Doddy Ariefianto \\ Perry Warjiyo ${ }^{1}$
}

\begin{abstract}
A bstraksi
Starting from the Optimum Currency Area (OCA), this paper utilize the Vector Error Correction Model (VECM) to identify the dynamic short term and the long term co-movement between the ASEAN 4 currencies, including their existing fundamental mechanism. There are at least 3 important findings, (i) the co-movement between the ASEAN 4 currencies is not proved empirically, (ii) the theory of OCA does not robust in explaining the co-movement pattern in ASEAN, and (iii) the existance of OCA is a global phenomena, indicated from the significance of Yen currency on the ASEAN 4. These findings led to a conclusion of this paper that the ongoing economic integration as well as the financial one in ASEAN are not enough to form a unified monetary arrangement nor a common currency in this region.
\end{abstract}

JEL Classification : F02, F36, F33, C32

Keywords: Pergerakan Bersama, Optimum Currency Area, Vector Error Correction Model.

1 Doddy Arifianto adalah Ekonom Senior Bank Mandiri (moch.ariefianto@bankmandiri.co.id and ), Dr. Perry Warjiyo adalah Direktur Riset Ekonomi dan Kebijakan Moneter Bank Indonesia, (perry_w@bi.go.id). 


\section{PENDAHULUAN}

Penelitian ini melakukan investigasi terhadap faktor/mekanisme fundamental yang bekerja dibalik keberadaan co-movement (jika ada) pada suatu pasangan mata uang. Tentunya diharapkan dengan menggunakan mata uang yang nilainya ditetapkan oleh pasar, keberadaan mekanisme fundamental akan lebih jelas terlihat. Hal ini terutama disebabkan minimalnya distorsi, misalnya dalam bentuk intervensi Bank Sentral/Pemerintah.

Implikasi dari adanya keberadaan co-movement dapat bersifat ekonomi dan politis. Dari sisi ekonomi jika sekelompok negara ternyata memiliki mata uang yang berkorelasi sangat erat, maka secara implisit kelompok negara tersebut dapat menggabungkan mata uangnya. Dengan kata lain negara tersebut dapat melepaskan kekuasaan moneternya dan memberikan kepada suatu badan supra nasional (dalam wadah ekonomi bersama).

Salah satu contoh yang paling sukses dari proses penggabungan ini adalah keberadaan European Monetary Union, (EMU) dan mata uang tunggal dengan European Central Bank $(E C B)$ sebagai bank sentralnya. Namun demikian proses kearah penggabungan moneter sebenarnya telah berlangsung cukup lama. Treaty Of Rome (1957) dapat dikatakan titik tolak yang meletakkan dasar/fase yang harus ditempuh dalam rangka pembentukan komunitas ekonomi eropa.

Salah satu studi penting yang melakukan penelitian terhadap kesiapan prasyarat OCA di ASEAN dan perbandingan versus Uni Eropa dilakukan oleh Bayoumi dan Mauro (1999). Mereka berpendapat bahwa negara-negara ASEAN telah mencapai level yang sama dengan Uni Eropa sebelum traktat Maastricth 1991 pada beberapa aspek. Aspek tersebut adalah

1. Perdagangan intra wilayah (yang diukur oleh share perdagangan internal terhadap GDP).

2. Komposisi perdagangan berdasarkan type produk. Dengan berlangsungnya transisi ekonomi, negara-negara di wilayah ini (kecuali Singapura) memiliki tendensi sebagai negara manufaktur.

3. Pola goncangan ekonomi. Meskipun dampak goncangan adalah lebih besar di ASEAN tetapi kecepatan pemulihan lebih tinggi di wilayah ini. Dengan demikian dapat dikatakan hasil bersih dari pola goncangan ekonomi semacam ini adalah cenderung netral.

Namun demikian mereka juga menemukan beberapa faktor yang dianggap dapat mengurangi daya tarik penyatuan moneter bagi wilayah ASEAN. Faktor-faktor ini adalah

1. Diversifikasi budaya dan system politik di ASEAN cenderung lebih tinggi dibandingkan Uni Eropa

2. Diversifikasi perdagangan yang signifikan. Meskipun US, Jepang dan Zona Eropa adalah rekan dagang utama, namun proporsi masing-masing adalah heterogen. Hal ini berimplikasi 
bahwa setiap negara ASEAN memiliki suatu goncangan spesifik pada level tertentu.

3. OCA index (Eichengreen dan Bayoumi, 1996) menunjukkan kesiapan negara ASEAN masih kalah dengan negara Eropa pra traktat Maastricth. Disini ditunjukkan divergennya arah keterkaitan mata uang ASEAN terhadap salah satu mata uang utama dunia. Singapura, Malaysia dan Philipina misalnya, lebih cocok masuk sebagai blok USD. Sedangkan Indonesia dan Thailand cenderung kepada blok JPY.

Hasil ini mengkonfirmasi temuan empiris Frankel dan Wei (1994), Kim dan Ryou (2001) dan Alesina et al (2002) bahwa permasalahan yang dihadapi dalam penyatuan keuangan negaranegara ASEAN adalah tidak adanya suatu mata uang anchor yang tunggal bagi mata uang negara ASEAN tersebut.

Dari sisi institusi, aktivitas ditingkat ofisial tentang keberadaan OCA dapat dikatakan langka. Beberapa lembaga kerjasama regional telah ada diwilayah ini, misalnya ASEAN, AFTA dan SEACEN, ASEAN misalnya bahkan telah berdiri sejak 1967. Namun demikian diskursus mengenai suatu kerjasama regional yang lebih erat melalui kerjasama moneter (dan mata uang bersama) baru terdengar pasca krisis keuangan Asia 1997. Era sebelum ini suatu kerjasama moneter yang lebih serius tampaknya terkendala oleh keberadaan rezim nilai tukar yang heterogen diwilayah Asia (Wilson, 2002).

Tahun 1997, Jepang menawarkan ide Asian Monetary Fund (AMF). Hal ini merupakan wujud dari kesadaran terhadap perlunya suatu dana emergency yang siap digunakan ketika dibutuhkan. Tampaknya ini juga merupakan reaksi kecewa terhadap sikap lamban IMF dalam mengatasi krisis Asia. Ide ini memperoleh resistensi keras dari IMF (dan stake holder utamanya US) sehingga akhirnya gagal diwujudkan. Sebagai pengganti, dalam kerangka ASEAN+3 suatu kesepakatan dalam hal penyediaan dana emergency diwujudkan dalam bentuk pejanjian swap. Inisiatif ini dikenal sebagai Chiang Mai Initiatives. Dari forum ini tampaknya terlihat adanya perkembangan kearah suatu instrument obligasi Asia.

Dari sisi upaya penyatuan mata uang, negara-negara diwilayah ini terlihat jauh lebih "kaku". Meskipun dibawah Hanoi Plan Action dibulan Desember 1998, pemimpin wilayah ASEAN sepakat untuk memulai suatu studi kelayakan atas adopsi mata uang bersama. Namun baru Januari 2001, suatu proyek resmi untuk penelitian ini dimulai (Wilson, 2002). Proyek ini dikenal dengan nama Kobe Research Project.

Meskipun ditingkat pengambil kebijakan arah penyatuan moneter adalah bergerak lamban, pra kondisi bagi negara Asia sebenarnya telah ada. Eichengreen dan Bayoumi (1996) dalam suatu studinya berkesimpulan bahwa wilayah Asia Timur telah memenuhi persyaratan standar OCA serta telah memiliki kesiapan yang sama dengan wilayah zona Eropa. Bayoumi dan Mauro 
(1999) juga mengusulkan hal yang serupa, namun dengan mesyaratkan perlunya suatu komitmen politik untuk memastikan bahwa proyek ini akan berhasil. Proposal lainnya dapat dilihat misalnya Wilson (2002), Mundel (2003), dan Branson dan Healy (2005).

Syarat dan kondisi teoritis dimana penyatuan mata uang adalah menguntungkan merupakan subyek dari teori Optimum Currency Area (OCA). Teori OCA modern secara komprehensif diuraikan oleh Robert Mundell (1961) dalam seminal paper nya yang berjudul "A Theory Of Optimum Currency Areas". Secara ringkas teori tersebut menguraikan bahwa sekelompok negara dapat memperoleh manfaat yang lebih besar dengan melepaskan penggunaan mata uang sendiri dan (secara bersama) mengadopsi mata uang lain atau menerapkan rezim nilai tukar tetap (khususnya antar mata uang negara anggota OCA).

Manfaat yang lebih besar ini dapat terjadi karena berbagai hal misalnya signifikannya transaksi perdagangan internal anggota OCA, mobilitas faktor produksi yang tinggi, korelasi siklus bisnis dsb. Dalam kondisi ini manfaat yang diperoleh dengan tetap menggunakan mata uang sendiri (berupa seignorage dan independensi kebijakan moneter) lebih kecil dari manfaat yang diperoleh dari penyatuan mata uang (berupa biaya transaksi yang rendah, stabilitas dan kredibilitas kebijakan).

Dengan asumsi serangkaian kondisi tersebut dipenuhi maka penelitian ini dilakukan untuk mengidentifikasi keberadaan OCA di wilayah Asia khususnya antara negara-negara: Indonesia, Singapura, Phillipina dan Thailand (ASEAN4). Secara lebih spesifik permasalahan penelitian ini diselesaikan dengan menjawab tiga pertanyaan, pertama,Apakah terdapat suatu co-movement yang secara statistik berarti pada mata uang negara Asia?; kedua, Apakah sejumlah kriteria yang dirujuk dalam teori OCA seperti perbedaan inflasi, pendapatan nasional, suku bunga dan jumlah uang beredar antar negara dapat digunakan sebagai faktor penjelas dari co-movement mata uang negara Asia tersebut?; dan ketiga, Apakah co-movement mata uang negara Asia tersebut lebih merupakan fenomena pergerakan nilai tukar mata uang global (JPY)?

Bagian kedua dari paper ini mengulas tinjauan teori, model teoritis dan beberapa studi literatur utama tentang pembentukan OCA. Bagian ketiga mengulas tentang metodologi khsusunya model empiris yang digunakan untuk menjawab ketiga pertanyaan penelitian yang diajukan. Bagian keempat mengulas hasil dan analisis sementara kesimpulan dan saran kebijakan menjadi penutup.

\section{TEORI}

Pemikiran klasik mengenai penyatuan ekonomi (dalam bentuk penyatuan mata uang) dapat ditelusuri paling tidak sejak John Stuart Mill (1848, hal 176), dimana ia menulis 
"....so much barbarism, however still remains in the transactions of most civilized nations that almost all independent countries choose to assert their nationality by having, to their own convenience and that of their neighbours, a peculiar currency of their own."

Paradigma pemikiran Mill (yang juga sebagaimana ekonom klasik lainnya) didasarkan pada suatu dunia yang semua aspek ekonominya adalah fleksibel. Dengan demikian sebenarnya suatu goncangan ekonomi dapat diatasi melalui penyesuaian variabel riil (misalnya perpindahan faktor produksi) tanpa melibatkan suatu variabel nominal (misalnya nilai tukar). Sebagai contoh jika di permintaan ekspor negara A turun secara drastis (karena pergeseran pola konsumsi dunia) maka faktor produksi dinegara tersebut dapat digunakan untuk produksi lain (baik dinegara tersebut maupun di negara lainnya) dan dengan demikian terjadi equilibrium baru. Penyesuaian diasumsikan berlangsung seketika (karena absennya hambatan) sehingga suatu deviasi variabel nominal yang substansial tidak akan bertahan lama.

Pemikiran yang lebih modern dan komprehensif mengenai teori OCA diuraikan oleh seminal paper Robert Mundel yang berjudul A Theory Of Optimum Currency Areas pada tahun 1961. Dari sini teori OCA terus berkembang, dimana dengan mengikuti struktur dari Mongeli (2002) ia dapat dibagi dalam beberapa fase, yakni² :

1. Fase Awal (1960-an s/d awal 1970-an). Fase ini dikarakteristikkan oleh kondisi dunia yang umumnya menganut nilai tukar tetap (Bretton Wood) dan pengawasan devisa. Disini timbul ide-ide yang mempertanyakan manfaat dan biaya antara rezim nilai tukar tetap dan nilai tukar fleksible serta kemungkinan integrasi ekonomi (khususnya di Eropa). Dari periode ini lahir kriteria yang harus dipenuhi agar manfaat integrasi ekonomi (dan penyatuan mata uang) dapat optimal. Mundel (1961), Ingram (1962), McKinon (1963), Kenen (1969), Grubel (1970), Mintz (1970), Fleming (1971) dan Corden (1972) adalah beberapa tulisan awal dibidang OCA.

2. Fase Rekonsiliasi (1970-an). Pada fase ini teori OCA dikembangkan dengan menggunakan kerangka berfikir manfaat versus biaya (lihat Corden, 1972 dan Mundell, 1973). Jika suatu wilayah (atau sekelompok negara) teridentifikasi sebagai OCA maka wilayah tersebut dapat melakukan penyatuan mata uang (kebijakan moneter bersama). Implikasi kebijakan semacam ini akan memberi suatu manfaat namun juga memiliki suatu biaya. Warjiyo (2004) membuat suatu rangkuman atas manfaat dan biaya dimaksud, yang dapat dilihat pada tabel IV.1.

2 Lihat Horvath (2003) dan Hawkins and Mason (2003) untuk suatu survey teori OCA dalam pandangan yang berbeda. 


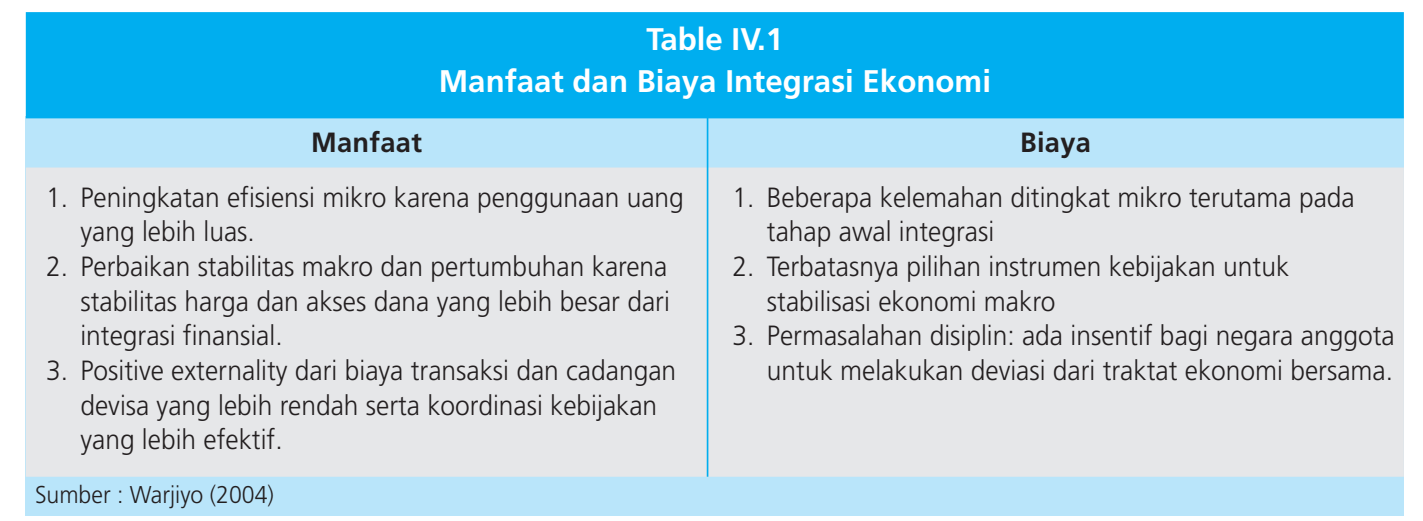

3. Fase Reassement (1980-an s/d 1990-an). Dilatari oleh laporan "One Market, One Money Report" (Emerson et al, 1992), ditemukan beberapa aspek dari teori OCA (yang lama) untuk disesuaikan. Aspek-aspek tersebut meliputi;

a. Tidak efektifnya kebijakan moneter terhadap output jangka panjang (fenomena short run Phillips Curve). Hal ini mengurangi biaya dari hilangnya kebijakan moneter yang independen (akibat integrasi ekonomi).

b. Diperlukan kredibilitas yang besar untuk membantu mengurangi biaya pengendalian inflasi didalam negara anggota OCA.

c. Penyesuaian nilai tukar tidak efektif didalam mempengaruhi sektor riil. Hal ini disebabkan adanya proses transmisi melalui capital account.

d. Dampak mata uang tunggal semakin kecil terhadap pasar tenaga kerja, yang disebabkan desentralisasi negosiasi kontrak ditingkat perusahaan.

4. Fase Empiris (1990-an). Upaya untuk mengoperasionalisasikan OCA semakin meningkat dengan adanya proyek Uni Eropa (dengan mata uang tunggalnya: Euro). Dapat dikatakan Uni Eropa adalah "landmark" yang sangat penting bagi pengembangan teori OCA. Dalam fase ini, teori OCA berkembang melalui uji empiris terhadap karakteristik dan model teoritis (lihat misalnya Frankel dan Rose (1996), Alesina et al (2002), dan Baele (2004)).

Sejalan dengan perkembangan pemikiran OCA, definisi OCA juga berkembang. Definisi terkini dan paling komprehensif diberikan oleh Mongeli (2002) dimana OCA didefinisikan sebagai:

"Optimal geographic domain of a single currency, or of several currencies, whose exchange rates are irrevocably pegged and might be unified. The single currency, or the pegged currencies can only fluctuate in unison against the rest of the world"

Dapat dilihat disini, OCA memiliki dua kata kunci, yakni (i) OCA domain yang didefinisikan sebagai negara yang berdaulat yang memilih untuk mengadopsi mata uang tunggal atau 
memberlakukan nilai tukar tetap (terhadap sesama negara angota OCA) yang permanen, (ii) Optimality, yang didefinisikan sebagai sifat/karakter dimana manfaat penyesuaian ekonomi makro (internal dan eksternal) dari nilai tukar secara sendiri-sendiri (oleh OCA domain) akan berkurang dibandingkan penggunaan mata uang bersama atau nilai tukar bilateral yang bersifat tetap dan permanen. Dengan kata lain, sekelompok negara akan membentuk OCA jika manfaat yang diberikan dari keanggotaan OCA lebih besar dari kerugian karena kehilangan kendali kebijakan moneter.

Untuk mencapai optimalitas wilayah mata uang bersama perlu dipenuhi beberapa karakteristik tertentu. Karakteristik ini menunjukkan kondisi yang diperlukan agar manfaat OCA yang diperoleh para anggotanya dapat maksimal. Tabel IV.2 dibawah ini merangkum karakteristik OCA dimaksud (Mongeli, 2002).

\begin{tabular}{|c|c|c|}
\hline & Persy & $\begin{array}{l}\text { Table IV.2 } \\
\text { atan Optimum Currency Area }\end{array}$ \\
\hline No. & Karakteristik OCA & Persyaratan Untuk OCA \\
\hline 1. & Fleksibilitas harga dan upah & $\begin{array}{l}\text { Fleksibilitas harga dan upah didalam dan diantara negara OCA } \\
\text { memperkecil penyesuaian nilai tukar apabila terjadi kejutan. }\end{array}$ \\
\hline 2. & Mobilitas faktor produksi & $\begin{array}{l}\text { Mobilitas faktor produksi, termasuk tenaga kerja, antar negara OCA } \\
\text { memperkecil penyesuaian harga faktor produksi dan nilai tukar terhadap } \\
\text { kejutan }\end{array}$ \\
\hline 3. & Integrasi pasar keuangan & $\begin{array}{l}\text { Integrasi finansial dalam bentuk mobilitas modal (FDI, portfolio } \\
\text { investment, pinjaman) antar negara OCA memungkinkan penyesuian } \\
\text { kejutan melalui aliran modal. }\end{array}$ \\
\hline 4. & Tingkat keterbukaan ekonomi & $\begin{array}{l}\text { Keterbukaan ekonomi antara negara OCA yang tinggi akan memperbesar } \\
\text { transmisi harga internasional ke harga domestik }\end{array}$ \\
\hline 5. & Diversifikasi produksi dan konsumsi & $\begin{array}{l}\text { Keberagaman tenaga kerja, sektor ekonomi dan produksi antar negara } \\
\text { OCA memperkecil penyesuaian Term Of Trade }\end{array}$ \\
\hline 6. & Kesamaan tingkat inflasi & $\begin{array}{l}\text { Kesamaan inflasi (dalam arti rendah dan stabil) antar negara OCA } \\
\text { mendorong stabilitas term of trade dan menyeimbangkan current } \\
\text { account. }\end{array}$ \\
\hline 7. & Integrasi fiscal & $\begin{array}{l}\text { Sistem transfer fiskal antar negara OCA memungkinkan distribusi dana ke } \\
\text { negara yang membutuhkan. }\end{array}$ \\
\hline 8. & Integrasi politis & $\begin{array}{l}\text { Kemauan politik memperkuat kepatuhan komitmen bersama, kerjasama } \\
\text { berbagai kebijakan ekonomi, dan hubungan kelembagaan antar negara } \\
\text { OCA. }\end{array}$ \\
\hline & : Mongeli (2002) & \\
\hline
\end{tabular}

Pada satu dekade belakangan ini berkembang suatu pemikiran kontemporer didalam teori OCA. Berbeda dengan pola pemikiran sebelumnya dimana wilayah moneter bersama akan optimal jika negara-negara anggotanya memenuhi syarat karakteristik OCA, Frankel dan Rose (1998), justru berpendapat sebaliknya: karakteristik OCA adalah bersifat endogen. Dengan kata lain sekelompok negara dapat saja tidak memenuhi satu-lebih karakteristik OCA ex ante 
tetapi suatu penyatuan moneter akan optimal ex post. Penelitian yang mereka lakukan terhadap dua puluh negara industri memberikan dukungan empiris. Lebih lanjut, Corsetti dan Pesenti (2002) memberikan suatu model formal mengenai aspek ini yang berangkat dari teori keseimbangan umum, dan disebut dengan model self validating OCA.

\section{II.1. Model Teoritis}

Kerangka teoritis studi ini dibangun dari model pendekatan moneter harga fleksibel (flexible price monetary approach, FLMA) ${ }^{3}$. FLMA berawal dari kritik terhadap penentuan nilai tukar yang menggunakan pendekatan flow neraca pembayaran. Mussa (1979) berargumen bahwa penentuan nilai tukar tersebut seharusnya didekati dengan pendekatan harga aset (karena nilai tukar adalah harga relatif mata uang domestik terhadap mata uang lainnya).

Jika nilai tukar dipandang sebagai harga aset maka terdapat implikasi berikut (MacDonald, 1988):

1. Faktor ekspektasi akan bersifat penting didalam penentuan nilai tukar. Hal ini terjadi karena daya tahan uang yang cukup tinggi (durability). Dengan demikian perubahan ekspektasi dimasa depan akan mempengaruhi nilai tukar saat ini.

2. Karena aset adalah suatu konsep stok, maka ekuilibrium didefinisikan sebagai situasi dimana stok permintaan mata uang akan sama dengan stok penawaran uang. Dengan demikian flow neraca pembayaran tidak dapat digunakan dalam penentuan nilai tukar karena ia hanya merupakan situasi disekuilibrium yang bersifat sementara. Ini adalah titik sentral dari pemikiran penganjur pendekatan moneter terhadap nilai tukar.

3. Faktor riil dapat mempengaruhi nilai tukar, namun hanya melalui faktor permintaan uang.

4. Empirical regularities berupa: (1) spot rate dan forward rate memiliki korelasi erat, (2) nilai tukar berperilaku random walk (dari hipotesa efisiensi pasar, lihat Fama (1970)), (3) forward rate dapat digunakan sebagai ekspektasi nilai tukar dan (4) informasi baru yang relevan akan mengubah nilai tukar saat ini.

Sebelum menguraikan model secara mendetail, terlebih dahulu diasumsikan beberapa hal (MacDonald, 1988 dan Gartner, 1993):

1. Ekonomi dunia dibagi dua, yakni domestik dan dunia (world) dengan variabel-variabel makro ekonomi terkait.

2. Small economy, dalam artian nilai variabel ekonomi domestik tidak memiliki dampak bagi perekonomian dunia.

3. Perekonomian domestik dan dunia selalu dalam kondisi full employment.

3 Tulisan Frenkel (1976), Mussa (1976) dan Bilson (1978) dapat dianggap sebagai perintis model FLMA. 
4. Pasar uang dan pasar barang selalu mencapai kondisi ekuilibrium (jika terjadi goncangan).

5. Pasar uang dalam dan luar negeri memiliki karakteristik serupa.

6. Terpenuhinya uncovered interest rate parity.

7. Fleksibilitas harga dan purchasing power parity/PPP berlaku

8. Constant Real Exchange Rate.

Konvensi notasi bagi variabel didalam model, adalah

\begin{tabular}{|c|c|c|c|}
\hline y & : pendapatan nasional & r & suku bunga domestik \\
\hline$y^{*}$ & : pendapatan dunia & & suku bunga dunia \\
\hline S & $\begin{array}{l}\text { : nilai tukar (dalam } X \text { mata uang domestik } \\
\text { per mata uang dunia) }\end{array}$ & M & penawaran uang domestik \\
\hline$p^{*}$ & : tingkat harga dunia & $M^{*}$ & penawaran uang dunia \\
\hline $\mathrm{p}$ & : tingkat harga domestik & & tingkat depresiasi \\
\hline g & : pengeluaran pemerintah domestik & & \\
\hline
\end{tabular}

semua notasi diatas (kecuali suku bunga) adalah dalam bentuk logaritma natural $\left(\mathrm{y}=\ln (\mathrm{Y}) ; \mathrm{Y}=\right.$ pendapatan nasional dalam rupiah) ${ }^{4}$.

Model FLMA secara sederhana dapat dijabarkan dalam persamaan-persamaan berikut:

\section{Persamaan sektor riil (IS Curve):}

$y=\delta\left(s+p^{*}-p\right)+\gamma y^{*}+\beta r+g$

dimana $\delta>0$ (Marshall-Lerner Condition terpenuhi), $\gamma>0, \beta<0$

2. Sektor Moneter:

$$
\begin{aligned}
& m-p=\phi y-\lambda r \\
& m^{*}-p^{*}=\phi y^{*}-\lambda r *
\end{aligned}
$$

dengan asumsi: $\phi>0, \lambda>0$ (permintaan uang ala Cagan)

\section{Pasar Asset (kondisi Uncovered Interest Parity):}

Untuk memperoleh nilai tukar yang menjamin ekuilibrium di ketiga pasar diatas, dapat dilakukan beberapa operasi matematis sbb:

$$
r=r^{*}+E(s)
$$

4 Pemodelan semacam ini memberikan manfaat intrepretasi statika komparatif. Dalam bentuk logaritma natural koefisien yang dihasilkan dari turunan pertama suatu variabel terhadap variabel lainnya adalah suatu elastisitas. Misalnya $y=a x$, maka $d / d x(y)=a d / d x(x)=$ $1 / y y^{\prime}=a x^{\prime} / x$ sehingga $a=y^{\prime} / y: x^{\prime} / x$ yang merupakan suatu elastisitas. 
atur kembali persamaan IV.1 sebagai

$p-p^{*}=s+\frac{1}{\delta}(-y+\gamma y *+\beta r+g)$

dari persamaan IV.2 dan IV.3, dapat diperoleh

$$
\begin{aligned}
p-p^{*} & =m-\phi y+\lambda r-\left(m^{*}-\phi y^{*}+\lambda r^{*}\right) \\
& =\left(m-m^{*}\right)-\phi\left(y-y^{*}\right)+\lambda\left(r-r^{*}\right)
\end{aligned}
$$

Atur kembali persamaan IV.5 dan substitusikan persamaan IV.6

$$
\begin{aligned}
s & =\left(p-p^{*}\right)-\frac{1}{\delta}\left(-y+\gamma y^{*}+\beta r+g\right) \\
s & =\left(m-m^{*}\right)-\phi\left(y-y^{*}\right)+\lambda\left(r-r^{*}\right)-\frac{1}{\delta}\left(-y+\gamma y^{*}+\beta r+g\right) \\
& =\left(m-m^{*}\right)-\phi\left(y-y^{*}\right)+\lambda\left(r-r^{*}\right)+\frac{1}{\delta} y-\frac{\gamma}{\delta} y^{*}-\frac{\beta}{\delta} r-\frac{g}{\delta} \\
& =\left(m-m^{*}\right)+\frac{1-\phi \delta}{\delta} y+\frac{\phi \delta-\gamma}{\delta} y^{*}+\frac{\lambda \delta-\beta}{\delta} r-\lambda r^{*}-\frac{g}{\delta}
\end{aligned}
$$

dengan mensubstitusikan persamaan IV.4 kedalam persamaan IV.7 diperoleh

$$
\begin{aligned}
\mathrm{s} & =\left(m-m^{*}\right)+\frac{1-\phi \delta}{\delta} y+\frac{\phi \delta-\gamma}{\delta} y^{*}+\frac{\lambda \delta-\beta}{\delta}\left(r^{*}+E(\dot{s})\right)-\lambda r^{*}-\frac{g}{\delta} \\
& =\left(m-m^{*}\right)+\frac{1-\phi \delta}{\delta} y+\frac{\phi \delta-\gamma}{\delta} y^{*}-\frac{\beta}{\delta} r^{*}+\frac{\lambda \delta-\beta}{\delta} \dot{E(s)}-\frac{g}{\delta}
\end{aligned}
$$

Dengan asumsi real exchange rate adalah konstan, maka pers diatas dapat ditulis kembali sebagai

$$
\mathrm{s}=\left(\mathrm{m}-\mathrm{m}^{*}\right)+\frac{1-\phi \delta}{\delta} \mathrm{y}+\frac{\phi \delta-\gamma}{\delta} \mathrm{y} *-\frac{\beta}{\delta} \mathrm{r} *+\frac{\lambda \delta}{\delta}[\mathrm{E}(\dot{\mathrm{p}})-\mathrm{E}(\dot{\mathrm{p}} *)]-\frac{\mathrm{g}}{\delta}
$$

Akhirnya karena ekonomi juga diasumsikan dalam kondisi full employment maka ekspektasi inflasi akan sama dengan ekspektasi pertumbuhan uang beredar, atau

$$
\mathrm{s}=\left(\mathrm{m}-\mathrm{m}^{*}\right)+\frac{1-\phi \delta}{\delta} \mathrm{y}+\frac{\phi \delta-\gamma}{\delta} \mathrm{y}^{*}-\frac{\beta}{\delta} \mathrm{r}^{*}+\frac{\lambda \delta-\beta}{\delta}[\mathrm{E}(\dot{\mathrm{m}})-\mathrm{E}(\dot{\mathrm{m}} *)]-\frac{\mathrm{g}}{\delta}
$$


perilaku nilai tukar dapat diturunkan sebagai berikut:

$$
\begin{aligned}
& \frac{\partial s}{\partial m}=1+\frac{\lambda \delta-\beta}{\delta} \frac{d E(\dot{m})}{d m}>15 ; \frac{\partial s}{\partial m^{*}}=-1-\frac{\lambda \delta-\beta}{\delta} \frac{d E(\dot{m})}{d m^{*}}<0 ; \frac{\partial s}{\partial r^{*}}=-\frac{\beta}{\delta}>0 \\
& \frac{\partial s}{\partial g}=-\frac{1}{\delta}<0
\end{aligned}
$$

dan

$\frac{\partial s}{\partial y}$ dan $\frac{\partial s}{\partial y^{*}}$ dapat mengambil nilai apapun

Model FLMA diatas baru membahas 4 dari 8 karakteristik OCA, yakni Integrasi Pasar Keuangan, Tingkat Keterbukaan Ekonomi, Kesamaan Tingkat Inflasi dan Integrasi Fiskal. Dengan demikian model ini masih belum lengkap. Untuk membahas perilaku nilai tukar terhadap karakteristik OCA yang belum tercakup, model diatas dapat diperluas kembali. Hal ini dilakukan sbb:

1. Penggunaan fungsi produksi $Y=F(X)$ yang merupakan suatu kelas khusus dari fungsi produksi CRTS (Constant Return To Scale), yakni fungsi produksi Cobb-Douglas ${ }^{6}$. Dalam bentuk log linear fungsi ini dapat ditulis sebagai

$y=\sum_{i=1}^{n} \alpha_{i} x_{i} ; \sum_{i=1}^{n} \alpha_{i}=1 i^{7}$

Dimana $x_{i}=\ln \left(X_{i}\right)$

2. Dengan mengasumsikan pula bahwa perusahaan adalah bersifat (1) price taker (berada dalam pasar persaingan sempurna) dan (2) bertujuan tunggal : memaksimumkan keuntungan, maka kita dapat merumuskan permasalahan produsen secara matematis sebagai:

5 Respon nilai tukar terhadap perubahan pertumbuhan jumlah uang beredar lebih dari proporsional (1:1). Hal ini oleh Bilson (1979) disebut dengan magnification effect.

6 Bentuk umum fungsi Cobb-Douglas adalah $Y=A \prod_{i=1}^{n} X_{i}^{\alpha_{i}}$, dengan asumsi CRTS maka: $\sum_{i=1}^{n} \alpha_{i}=1$ dan dengan demikian fungsi tersebut dapat ditulis kembali sebagai $Y=A \prod_{i=1}^{n} X_{i}^{\alpha_{i}} ; \sum_{i=1}^{n} \alpha_{i}=1$

7 Bukti: $Y=A \prod_{i=1}^{n} X_{i}^{\alpha_{i}} ;$ dengan asumsi $\mathrm{A}=1$ dan dengan mengambil nilai log maka fungsi produksi tersebut dapat ditulis kembali sebagai $\ln (Y)=\sum_{i=1}^{n} \alpha_{i} \ln \left(X_{i}\right)$ dimana $\sum_{i=1}^{n} \alpha_{i}=1$. Konsisten dengan konvensi, dimana huruf kecil adalah bentuk logaritma maka $y=\sum_{i=1}^{n} \alpha_{i} x_{i} ; \quad \sum_{i=1}^{n} \alpha_{i}=1$ seperti yang diinginkan. 
Min $\mathbf{w x}$

$x \geq 0$

st $f(x) \geq y$

dimana w: vektor harga input (dan $\mathbf{w}>>0$ ), y adalah vektor output yang dikehendaki. Solusi dari masalah ini adalah

$\mathbf{w} \geq \ddot{\mathbf{e}} \nabla \mathbf{f}\left(x^{o}\right)$ dan $\mathbf{w}-\ddot{\mathbf{e}} \nabla \mathbf{f}\left(x^{o}\right)=\mathbf{0}$

Dimana $\Delta \mathrm{f}(\mathrm{x})$ adalah gradient vector: $\frac{\partial f(x)}{\partial x}$

Dari solusi ini secara implisit kita dapat mendefinisikan $x^{\circ}$ sebagai fungsi harga input (w) dan output (y) atau

$$
\mathbf{x}^{\circ}=\mathbf{x}^{\circ}(\mathbf{w}, \mathbf{y})
$$

3. Dengan mensubstitusikan 15 kedalam 12 maka diperoleh

$$
\begin{aligned}
& y=\sum_{i=1}^{n} \alpha_{i} x(w, y)_{i} ; \sum_{i=1}^{n} \alpha_{i}=1 \\
& \text { Atau dalam kondisi optimisasi adalah } \\
& y=\sum_{i=1}^{n} \alpha_{i} x(w)_{i} ; \quad \sum_{i=1}^{n} \alpha_{i}=1
\end{aligned}
$$

4. Hasil yang terakhir ini dapat disubsitusikan kembali ke persamaan IV.10 dan memberikan

$$
\begin{aligned}
& \mathrm{s}=\left(m-m^{*}\right)+\frac{1-\phi \delta}{\delta} \sum_{i=1}^{n} \alpha_{i} x_{i}(w)+\frac{\phi \delta-\gamma}{\delta} \sum_{i=1}^{n} \alpha{ }_{i} x^{*}{ }_{i}(w)-\frac{\beta}{\delta} r * \\
& +\frac{\lambda \delta-\beta}{\delta}[E(\dot{m})-E(\dot{m} *)]-\frac{g}{\delta}
\end{aligned}
$$

Persamaan II.18 melengkapi seluruh pembahasan perilaku nilai tukar dari karakteristik OCA. Seperti yang dapat dilihat disini keberadaan komponen $\sum_{i=1}^{n} \alpha_{i} x(w)_{i}$ dan $\sum_{i=1}^{n} \alpha^{*}{ }_{i} x{ }_{i}(w)$ menunjukkan fleksibilitas harga dan upah, mobilitas faktor produksi dan diversifikasi produksi dan konsumsi.

Sebagai suatu rangkuman, model yang telah diturunkan diatas dapat diintrepretasikan sebagai berikut:

1. Nilai tukar adalah fungsi yang negatif terhadap selisih jumlah uang beredar dalam negeri dengan luar negeri. Dengan asumsi ekspektasi rasional, magnitude dari variabel selisih jumlah uang beredar akan bertambah lebih besar dari pada kondisi ekspektasi statis.

2. Goncangan pada sisi penawaran (upah, siklus bisnis, hubungan dagang, dsb) memiliki dampak yang tidak dapat ditentukan terhadap nilai tukar. Hal ini merupakan konsekuensi 
logis, mengingat parameter output agregat dari model tidak dapat memiliki tanda tertentu. 3. Peningkatan suku bunga luar negeri akan berdampak negatif terhadap nilai tukar domestik. 4. Dampak dari ekspansi fiskal adalah positif bagi nilai tukar domestik.

Kembali perlu ditekankan disini bahwa model ini mengasumsikan dunia yang hanya terdiri dari dua negara, generalisasi lebih lanjut pada kondisi banyak negara perlu memperoleh suatu catatan. Kerangka teori sebagaimana diuraikan diatas adalah valid jika ASEAN4 memiliki mata uang anchoryang sama (misalnya USD atau JPY). Dalam kondisi ini maka yang berperan sebagai pihak luar negeri (variabel dengan *) adalah US atau Jepang. Suatu varian yang menyangkut anchor ganda (keranjang mata uang) juga dapat diadaptasi sepanjang keranjang mata uang tersebut adalah identik untuk semua negara ASEAN4.

Dengan syarat asumsi diatas terpenuhi, model ini dapat menjelaskan pergerakan bersama mata uang ASEAN4 (jika terbukti secara statistik signifikan). Hal ini dapat diuraikan sbb:

1. Notasikan terlebih dahulu $\mathrm{s}_{\mathrm{j}}$ sebagai nilai tukar negara $\mathrm{j}$ (yang diduga merupakan anggota OCA yang terdiri atas n negara) terhadap suatu mata uang yang diduga sebagai benchmark (misalnya USD).

2. Adanya suatu OCA pada kelompok negara ini dapat dikarakteristikkan dengan terpenuhinya persamaan berikut

$\mathrm{s}=\mathrm{w}_{1} \mathrm{~s}_{1}=\mathrm{w}_{2} \mathrm{~s}_{2}=\ldots=\mathrm{w}_{\mathrm{n}} \mathrm{s}_{\mathrm{n}}$

dimana s adalah mata uang bersama OCA yang merupakan fungsi dari mata uang-mata uang anggota OCA $\left(\mathrm{s}_{\mathrm{i}} ; \mathrm{i}=1,2, \ldots, \mathrm{n}\right)$ dan $\mathrm{w}_{\mathrm{i}}$ adalah bobot mata uang $\mathrm{s}_{\mathrm{i}}$ didalam $\mathrm{s}$.

3. Apabila mata uang sekelompok negara diduga adalah OCA, maka koefisien $\mathrm{w}_{\mathrm{i}}$, harus memiliki tanda matematis yang sama (yakni positif). Magnitude dapat berbeda tergantung dari signifikansi ekonomi yang bersangkutan.

4. Implikasi dari FLMA adalah pergerakan variabel ekonomi makro harus konsisten dengan nilai tukar, karena

$$
\begin{aligned}
\mathrm{s} & =\mathrm{w}_{1} \mathrm{~s}_{1}\left[\left(\mathrm{~m}_{1}-\mathrm{m}^{*}\right),\left(\mathrm{y}_{1}-\mathrm{y}^{*}\right), \ldots\right]=\mathrm{w}_{2} \mathrm{~s}_{2}\left[\left(\mathrm{~m}_{2}-\mathrm{m}^{*}\right),\left(\mathrm{y}_{2}-\mathrm{y}^{*}\right), \ldots\right]=\ldots \\
& =\mathrm{w}_{\mathrm{n}} \mathrm{s}_{\mathrm{n}}\left[\left(\mathrm{m}_{\mathrm{n}}-\mathrm{m}^{*}\right),\left(\mathrm{y}_{\mathrm{n}}-\mathrm{y}^{*}\right), \ldots\right]
\end{aligned}
$$

Dengan kata lain, kebijakan maupun kondisi ekonomi negara yang tidak konsisten akan berdampak pada keluarnya negara tersebut dari OCA ${ }^{8}$.

Secara grafis konsep yang baru saja diuraikan diatas dapat dirangkum melalui Grafik IV.1. Seperti yang dilihat disini, seandainya Indonesia mengikatkan diri pada komitmen

8 Seperti yang dilihat nanti, penulis memasukkan variabel inflasi dan suku bunga secara terpisah kedalam model. Hal ini berpotensi menimbulkan masalah multikolinearitas. Namun demikian seperti yang dapat dilihat pada model formal yang diuraikan disini, inflasi perlu dimasukkan untuk menjadi proxy dari ekspektasi inflasi. Jika ekspektasi adalah sempurna maka dapat diharapkan suatu multikolinearitas sempurna (sangat tinggi), tetapi jika ekspektasi hanya bersifat rasional/adaptif maka multikolinearitas yang terjadi hanya bersifat ringan (dapat diabaikan). 


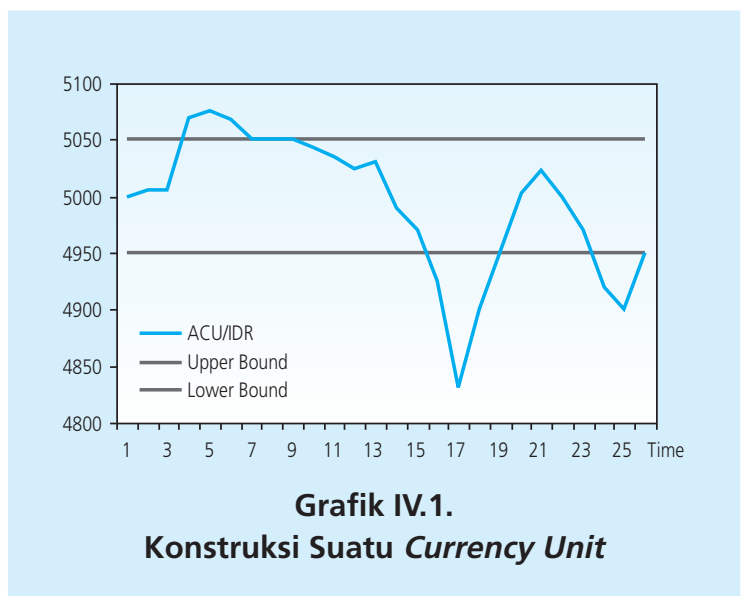

mata uang bersama ASEAN4 (sebut saja mata uangnya sebagai ASEAN Currency Unit; ACU), maka pergerakan IDR versus ACU harus berada didalam range yang disepakati. Jika IDR bergerak diluar range secara berkelanjutan, maka komitmen (dan kemampuan) IDR untuk tetap menjadi anggota wilayah moneter bersama ASEAN4 akan dipertanyakan.

Lebih lanjut sebagai konsekuensi OCA mata uang tersebut harus bergerak searah terhadap mata uang anchor. Penulis akan menjelaskan hal ini melalui suatu illustrasi. Anggap saja Indonesia dan Thailand adalah anggota ACU dengan nilai konversi 1 ACU = IDR 1000 dan 1 ACU = 10 THB. Kedua negara diketahui memiliki anchor terhadap USD dengan nilai tukar 1 USD = IDR 10.000 dan 1 USD = 100 THB. Saat ini nilai tukar internal (terhadap ACU) maupun eskternal (terhadap USD) adalah konsisten. Namun seandainya terjadi perubahan terhadap nilai tukar eksternal, khususnya IDR, misalnya menjadi 1 USD = IDR 5000 dan lainnya tetap, maka disini akan terdapat kesempatan arbitrage. Secara eksternal, nilai tukar 1 THB = IDR 50, sedangkan melalui ACU, 1 THB bernilai IDR 100. Keuntungan bebas risiko akan diperoleh dengan jalan membeli THB dengan IDR (melalui USD) dan (secara bersamaan) menjualnya melalui ACU.

\section{II.2. Beberapa Studi Empiris Terdahulu}

Salah satu studi empiris OCA yang sangat berpengaruh adalah karya dari Frenkel dan Wei (1993). Mereka mencoba melihat keberadaan blok dagang dan blok mata uang berdasarkan teori gravitasi. Teori ini memberikan hipotesis siap uji: intensitas dagang dan keterkaitan mata uang (co movement mata uang) adalah (1) berbanding lurus dengan ukuran ekonomi dan (2) berbanding terbalik dengan jarak. Sampel yang digunakan meliputi 63 negara diberbagai wilayah Dunia (Zona Eropa, Hemisfer Barat dan Asia) dengan berbagai periode observasi yang tidak 
identik. Dengan menggunakan teknik estimasi regresi pada first difference mereka menemukan bahwa mata uang suatu negara umumnya memiliki keterkaitan erat dengan mata uang utama dunia (USD, Yen dan Deustchmark). Untuk wilayah Eropa, Deutschmark adalah dominan sedangkan hemisfer barat dan Asia adalah USD.

Suatu studi yang secara lebih khusus mendalami hubungan mata uang diwilayah Asia (yakni IDR, THB, PHP, SGD, KRW, MYR) terhadap dua mata uang utama dunia, yakni USD dan JPY dilakukan oleh Takagi (1996). la menggunakan pendekatan deskriptif melalui pengamatan pada episode-episode dimana JPY bergerak fluktatif selama 1980-1995. Disini ia menduga bahwa peran JPY mungkin lebih signifikan dibandingkan estimasi ekonometris (khususnya hasil studi Frankel dan Wei (1993)) tetapi tidak simetris. Saat JPY mengalami tekanan depresiasi, mata uang Asia cenderung mengikuti. Dengan kata lain ada peningkatan bobot JPY pada penentuan nilai tukar mata uang negara Asia, disaat JPY mengalami depresiasi. Takagi (1996) berargumen bahwa hal ini terjadi dalam rangka menjaga agar ekspor tetap kompetitif. Sebaliknya ketika JPY dalam periode "tenang", bobot lebih banyak pada USD. Yang terakhir ini diduga dalam rangka upaya stabilitas inflasi domestik.

Metoda lain didalam menghitung relasi antar mata uang dilakukan oleh Kim dan Ryou (2001). Disini mereka mencoba mengestimasi bobot mata uang utama dunia (USD, JPY dan Deutcshmark) didalam penentuan nilai tukar beberapa negara Asia (yakni Korea, Singapura, Malaysia, Indonesia, Thailand, Philipina, Hongkong dan Taiwan). Bobot tersebut dihitung dengan melakukan regresi OLS antara mata uang i terhadap USD, JPY dan Deutcshmark pada denominator yang sama (Special Drawing Right/SDR). Disini mereka menemukan bahwa negara Asia tidak dapat dikarakteristikkan sebagi suatu blok mata uang tunggal (misalnya terhadap USD atau JPY). Lebih lanjut mereka menduga setting penentuan nilai tukar negara-negara tersebut adalah terhadap suatu keranjang mata uang.

Studi-studi diatas umumnya melakukan penelitian terpisah antara co-movement nilai tukar dengan co-movement variabel ekonomi makro lainnya atau hanya mempelajari salah satu aspek saja. Ini adalah suatu kelemahan. Interaksi antara nilai tukar dan variabel ekonomi makro dapat bersifat dua arah, semuanya adalah variabel endogen. Dengan demikian penelitian terhadap co-movement nilai tukar saja tanpa memasukkan variabel ekonomi makro dapat berujung pada masalah mis spesifikasi.

Kelemahan lain dari penelitian sebelumnya ada pada aspek metodelogi. Seluruh penelitian empiris yang diberikan diatas diestimasi dengan menggunakan OLS (atau variannya). Penggunaan teknik OLS memiliki beberapa kelemahan, yakni

1. Spurious regression. Umumnya penelitian dilakukan menggunakan data time series. Karakteristik khusus dari data ini adalah adanya fenomena autokorelasi (nilai suatu variabel 
saat ini dapat dijelaskan oleh nilai variabel tersebut pada waktu lampau). Dengan demikian estimasi LS antara dua variabel yang datanya memiliki karakteristik ini dapat menimbulkan masalah regresi palsu (Gujarati, 2003).

2. Endogeneity. Teknik LS mengasumsikan adanya arah hubungan yang jelas. Jadi ketika $Y$ diregresikan terhadap $X$, maka dalam model tersebut sekaligus diasumsikan bahwa $X$ adalah variabel penjelas dan $Y$ adalah variabel yang dijelaskan. Banyak hubungan antar variabel ekonomi bersifat simultan, sehingga menurut Sims (1980) seharusnya variabel-variabel tersebut diperlakukan pada equal footing.

3. Ad hoc process. Variabel-variabel ekonomi makro biasanya bersifat nonstationary/ integrated pada orde 1 atau 2 (Nelson dan Plosser, 1982). Padahal LS hanya valid jika variabel yang digunakan adalah stationary. Untuk mengatasi masalah ini, peneliti-peneliti sebelumnya melakukan perlakuan first differenced. Sims (1980) menentang teknik ini karena beranggapan teknik tersebut dapat membuang informasi berharga pada data.

4. Short term vs long term. Dengan menggunakan teknik LS, hubungan yang diperoleh belum tentu bersifat jangka panjang, bahkan mungkin hanya berlaku pada periode sampel. Dengan demikian untuk diperlukan suatu teknik yang dapat menunjukkan adanya hubungan ekuilibrium dan linear antara variabel-variabel yang nonstationary namun memiliki error yang stationary yang disebut dengan istilah kointegrasi (Enders, 1995).

Didalam paper ini, penulis mencoba melakukan beberapa perbaikan berdasarkan kelemahan yang telah diidentifikasi diatas. Perbaikan yang dilakukan meliputi:

1. Pemodelan yang memasukkan co-movement nilai tukar (versus dua anchor currency USD dan JPY) dan sekaligus co-movement variabel ekonomi makro lainnya (yakni tingkat harga, suku bunga, output nasional dan jumlah uang beredar). Namun demikian penulis membatasi bentuk hubungan sebagai nilai tukar adalah variabel dependen dan variabel ekonomi makro sebagai variabel independent (eksogen). Dengan demikian model yang digunakan adalah untuk keperluan (1) identifikasi adanya co-movement nilai tukar dan (2) penggunaan variabel ekonomi makro sebagai variabel kontrol (oleh sebab itu teori OCA adalah valid sebagai penjelas).

2. Perbaikan teknik estimasi, dengan alasan sebagaimana yang telah disebutkan diatas, paper ini tidak menggunakan OLS. Sebagai penggantinya digunakan teknik ekonometrika yang disebut dengan vector error correction modeINECM (Johansen, 1988) ${ }^{9}$.

9 VECM adalah suatu kelas dari Vector Auto Regressive Model yang dikenalkan oleh Sims (1980). Metoda ini adalah pengembangan dari persamaan simultan yang digunakan secara ateoritis. 


\section{METODOLOGI}

Hipotesis penelitian diuji dengan mengestimasi model hubungan antar variabel dalam bentuk vector error correction (VECM) sebagaimana diberikan oleh persamaan IV.21.

$$
\Delta \mathbf{Y}_{\mathrm{t}}=\sum_{i=1}^{k-1} \Gamma_{\mathrm{i}} \Delta \mathbf{Y}_{\mathrm{t}-\mathrm{i}}+\Pi \mathbf{Y}_{\mathrm{t}-\mathrm{k}}+\Phi \mathbf{X}_{\mathrm{t}}+\mu+\varepsilon_{\mathrm{t}}
$$

Untuk mengestimasi model ini, penulis menggunakan metoda Johansen (1988). Model empiris harus dapat menunjukkan bahwa variabel karakteristik OCA $\left(X_{t}\right)$ berpengaruh penting kepada co-movement mata uang ASEAN4. Hal ini dilakukan dengan mengeluarkan sebagian dari variabel karakteristik OCA sebagai variabel kontrol, yang diasumsikan bersifat eksogen terhadap nilai tukar. Mengingat OCA didefinisikan sebagai suatu wilayah yang penggunaan mata uang bersama akan memberikan hasil yang optimal maka dampak goncangan atau kebijakan terhadap suatu mata uang adalah sama dampaknya terhadap mata uang lain.

Sebagai contoh, seandainya Otoritas Moneter Thailand memutuskan untuk menaikkan jumlah uang beredar (ekspansi moneter), hal ini tidak hanya akan melemahkan THB terhadap USD (berdasarkan FLMA), namun juga seluruh mata uang negara ASEAN 4. Ini adalah OCA dalam bentuk yang paling ideal (sebut saja sebagai strong form OCA). Dalam bentuk lemahnya OCA diperkirakan sudah ada, cukup dengan adanya kointegrasi. Hal ini disebabkan terbatasnya variabel karakteristik OCA yang dimasukkan sebagai variabel eksogen/kontrol.

Karakteristik ketiga akan secara otomatis terjawab jika hubungan ekuilibrium yang diperoleh memiliki arah yang sama, misalnya IDR $=_{-}$SGD; dimana _>0. Bentuk yang paling ketat dari OCA mensyaratkan $\ldots=1$. Namun demikian disini, penulis menilai OCA telah teridentifikasi sepanjang _>0 dan secara statistik signifikan. Selanjutnya penulis juga tertarik untuk mengetahui kemungkinan adanya mata uang anchor lainnya, yang dalam paper ini dipilih JPY. Untuk menghindari kompleksitas representasi, variabel JPY (terhadap USD) digunakan sebagai variabel eksogen. Tentunya jika variabel ini memiliki koefisien yang positif dan signifikan, maka mata uang ASEAN4 juga memiliki anchor terhadap JPY.

Adapun variabel-variabel yang digunakan dapat diuraikan $\mathrm{sbb}^{10}$ :

1. IDR, SGD, PHP dan THB : nilai tukar dengan konvensi 1 USD sama dengan $X$ mata uang domestik.

2. XUS_INF: selisih inflasi antara ASEAN4 versus US

3. XUS_IRT: selisih perubahan suku bunga ASEAN4 versus US

10 Variabel yang digunakan adalah dalam bentuk log. Notasi $X$ didepan setiap variabel merujuk pada Indonesia (ID), Singapura(SG), Philipina(PH) dan Thailand(TH) sedangkan t adalah periode. 
4. XUS_GRW: selisih pertumbuhan GDP riil ASEAN4 versus US

5. XUS_M1C : selisih pertumbuhan M1 ASEAN4 versus US

6. JPY_FX: selisih pertama dari log JPY $\left(J P Y_{t}-J P Y_{t-1}\right)$.

Jumlah variabel yang digunakan pada studi ini adalah sebanyak 21 variabel. Data memiliki frekuensi bulanan dengan periode observasi meliputi 1997:09 s/d 2005:09 (97 observasi).

Pengujian OCA dilakukan secara 2 tahap. Tahap pertama adalah pengujian OCA bivariate yang hanya melibatkan dua mata uang ASEAN 4. Secara keseluruhan terdapat 6 (enam) kombinasi OCA bivariate, yakni:

1. OCA1: variabel endogen: IDR, SGD dan variabel eksogen:IDUS_INF, IDUS_IRT, IDUS_GRW, IDUS_M1C, SGUS_INF, SGUS_IRT, SGUS_GRW, SGUS_M1C dan JPY_FX.

2. OCA2: variabel endogen: IDR, PHP dan variabel eksogen: IDUS_INF, IDUS_IRT, IDUS_GRW, IDUS_M1C,PHUS_INF, PHUS_IRT, PHUS_GRW, PHUS_M1C dan JPY_FX.

3. OCA3: variabel endogen: IDR, THB dan variabel eksogen: IDUS_INF, IDUS_IRT, IDUS_GRW, IDUS_M1C, THUS_INF, THUS_IRT, THUS_GRW, THUS_M1C dan JPY_FX.

4. OCA4: variabel endogen: SGD, PHP dan variabel eksogen: SGUS_INF, SGUS_IRT, SGUS_GRW, SGUS_M1C,PHUS_INF, PHUS_IRT, PHUS_GRW, PHUS_M1C dan JPY_FX.

5. OCA5: variabel endogen: SGD, THB dan variabel eksogen: SGUS_INF, SGUS_IRT, SGUS_GRW, SGUS_M1C, THUS_INF, THUS_IRT, THUS_GRW, THUS_M1C dan JPY_FX.

6. OCA6: variabel endogen: PHP, THB dan variabel eksogen: PHUS_INF, PHUS_IRT, PHUS_GRW, PHUS_M1C, THUS_INF, THUS_IRT, THUS_GRW, THUS_M1C dan JPY_FX.

Tahap kedua dilakukan dengan memodelkan secara penuh seluruh 21 variabel di atas yakni: 4 mata uang, 16 variabel eksogen OCA dan JPY_FX (sebut saja sebagai OCA Model Lengkap).

Pentahapan ini dilakukan untuk memperoleh gambaran yang lebih komprehensif terhadap keberadaan OCA di ASEAN4. Jika terdapat konsistensi terhadap keberadaan OCA baik ditingkat bivariate maupun model lengkap, hal ini akan memberikan gambaran yang lebih kuat mengenai bagaimana OCA itu terbentuk.

Penggunaan VECM memungkinkan penelitian untuk melakukan estimasi hubungan jangka panjang dan jangka pendek secara sekaligus. Hal ini ditunjukkan dengan terpenuhinya persyaratan berikut:

1. Hubungan yang terbentuk adalah jangka pendek, jika variabel kointegrasi/error correction term tidak signifikan ${ }^{11}$.

2. Hubungan yang terbentuk adalah jangka panjang, jika variabel kointegrasi/error correction term adalah negatif dan signifikan.

11 Jika Error Correction Term positif dan signifikan, hubungan yang ada adalah eksplosif dan berarti system tidak konvergen. 
Untuk melakukan estimasi VECM, penulis mengikuti tahapan sebagaimana yang disarankan oleh Enders (1995) dan A.V. Hardiyanto (2004):

1. Uji derajat integrasi masing-masing variabel. Hal ini untuk memastikan bahwa variabelvariabel dalam analisis tidak memiliki orde integrasi yang berbeda.

2. Lakukan pemilihan lag Vektor Auto Regressive berdasarkan lag length criteria.

3. Lakukan pengujian Cointegration Test.

4. Estimasi dan Investigasi hasil proses Vektor Error Correction (VEC) dalam kaitan kriteria normality dan classical test.

5. Lakukan restriksi dan uji bahwa parameter yang ditemukan telah sesuai dengan hipotesis.

Hipotesis penelitian diuji dengan melihat terpenuhi tidaknya karakteristik berikut pada VECM:

1. Adanya pergerakan bersama diantara mata uang ASEAN4. Hal ini ditunjukkan oleh Impact matrix $(P)$, dimana koefisien penyesuaian $a_{i}$ adalah negatif dan signifikan. Hal ini berarti terdapat suatu hubungan ekuilibrium jangka panjang serta suatu mekanisme dari mana suatu deviasi hubungan ekuilibrium akan seimbang kembali.

2. Teori OCA dapat menjelaskan co-movement: karakteristik OCA yakni perbedaan inflasi, pendapatan nasional, suku bunga dan jumlah uang beredar antar negara dapat digunakan sebagai faktor penjelas dari co-movement mata uang negara Asia. Hal ini berlaku jika

a. Seluruh koefisien selisih tingkat harga ASEAN 4 dengan US adalah positif dan signifikan.

b. Seluruh koefisien selisih tingkat bunga ASEAN 4 dengan US adalah positif dan signifikan.

c. Seluruh koefisien selisih GDP riil ASEAN 4 dengan US adalah dapat bersifat positif atau negatif yang penting konsistensi arah dan signifikan ${ }^{12}$.

d. Selisih koefisien jumlah uang beredar ASEAN 4 dengan US adalah positif dan signifikan.

3. Pengaruh Global: mata uang ASEAN4 memiliki anchor mata uang yang identik (USD, JPY atau USD dan JPY). Hal ini ditunjukkan dengan matriks koefisien hubungan jangka pendek $\left(G_{i}\right)$ dan vektor hubungan kointegrasi (b) yang memiliki tanda koefisien yang sama (yakni positif) dan signifikan. Alternatifnya: jika koefisien tersebut adalah tidak signifikan tetapi koefisien JPY adalah signifikan (dengan mengambil tanda apapun) maka anchor bagi mata uang diwilayah ini adalah JPY. Penolakan terhadap kedua kondisi ini dapat diartikan absennya OCA yang didefinisikan terhadap anchor USD dan/atau JPY. Disisi lain jika kedua anchor

12 Berdasarkan persamaan 10 koefisien dari selisih GDP (ASEAN4 versus US) adalah $\frac{1-\phi \delta}{\delta} y+\frac{\phi \delta-\gamma}{\delta} y *$, nilai parameter ini tidak dapat ditentukan didepan karena besaran _ _- dan $\phi$ tidak diketahui. Disini ditekankan pada konsistensi, respon nilai tukar. Jika pada IDR, kenaikan GDP adalah bersifat depresiatif maka pada SGD, THB dan PHP juga harus bersifat depresiatif. 2 Model terbaik yang dianggap mencerminkan persamaan kointegrasi akan dilihat dari nilai kriteria informasi (digunakan AIC dan SIC). Model yang terpilih adalah model dengan nilai kriteria informasi terendah pada lag kointegrasi. 
diatas adalah signifikan maka mata uang ASEAN4 diduga memiliki jangkar terhadap suatu keranjang mata uang dimana baik USD maupun JPY menempati porsi yang dominan.

4. Jika koefisien sebagaimana dimaksud pada poin 1, 2 atau 3 tidak berbeda nyata dari nol atau diperoleh hasil yang divergen, maka disimpulkan persyaratan OCA dari studi ini tidak terpenuhi.

Terkait dengan verifikasi hipotesis, disini dapat diberikan suatu catatan sbb:

1. Model bivariat dan model lengkap adalah pentahapan verifikasi hipotesis dengan demikian model bivariate akan menjadi support bagi model lengkap. Dengan perkataan lain, tanda aljabar koefisien dan signifikansi yang diperoleh seharusnya adalah serupa.

2. Apabila terjadi perbedaan antara kedua model dimaksud, maka akan dilihat model dengan ukuran signifikansi statistik yang lebih tinggi baik secara parsial maupun keseluruhan (goodness of fit).

3. Kesimpulan selanjutnya dilakukan secara statistik. Jika model parsial memiliki ukuran statistik yang lebih baik, maka dapat disimpulkan bahwa dukungan empiris OCA dilevel ASEAN4 adalah rendah. Dalam hal ini OCA terdefinisi lebih baik secara bilateral.

4. Ketidak sesuaian terhadap hipotesis dipandang sebagai suatu gradasi terhadap persyaratan OCA. Maintained hypotheses adalah terdapat OCA di ASEAN 4. Hipotesis ini memperoleh dukungan paling kuat jika seluruh koefisien memiliki tanda aljabar yang sesuai dan signifikan secara statistik. Semakin banyak tanda aljabar atau koefisien yang tidak signifikan maka semakin besar gradasi deviasi terhadap keberadaan OCA.

\section{HASIL DAN ANALISIS}

Bagian Hasil dan Analisis akan menguraikan hasil estimasi dan analisa atas temuan empiris. Sub bagian pertama akan dikemukakan hasil pretest dan validasi model yang terdiri atas pengujian stasioneritas dan kointegrasi variabel yang digunakan (termasuk pemilihan lag optimal). Dalam bagian Pre Test dan Validasi Model juga dilakukan uji stabilitas dan pelanggaran asumsi klasik. Pada sub bagian kedua akan dibahas tentang fenomena co-movement yang ditemui serta variabel yang mempengaruhinya. Akhirnya pembahasan akan ditutup dengan suatu pendapat mengenai eksistensi OCA serta evaluasi (assestment) atas pemenuhan persyaratan empiris yang telah diperoleh.

\section{IV.1. Pre Test dan Validasi Model}

Tabel IV.3 menunjukkan bahwa kecuali IDR, variabel nilai tukar adalah berderajat integrasi $1(I(1))$. Disini kami kira IDR mengalami permasalahan yang disebut near stationary. Seperti 
yang diuraikan Harris (1995), salah satu permasalahan didalam pengujian unit root, adalah rendahnya power dan size dari pada teknik pengujian. Untuk itu tampaknya lebih baik menganggap bahwa sifat data IDR adalah non stationary.

\begin{tabular}{|c|c|c|c|c|c|c|c|c|c|c|}
\hline \multirow{3}{*}{ No. } & \multirow{3}{*}{ Variabel } & \multicolumn{8}{|c|}{ Table IV.3 } & \multirow{3}{*}{ Kesimpulan } \\
\hline & & \multicolumn{4}{|c|}{ ADF } & \multicolumn{4}{|c|}{ Phillips-Perron } & \\
\hline & & Model & Lag & t stat & $p$ value & Model & Bandwidth & t stat & $p$ value & \\
\hline \multirow[t]{2}{*}{1} & IDR (Lv) & Constant & 5 & -3.76 & 0.005 & Trend & 8 & -5.04 & 0.000 & \multirow[t]{2}{*}{ I(0) } \\
\hline & IDR (1d) & None & 4 & -4.42 & 0.001 & Constant & 12 & -7.52 & 0.000 & \\
\hline \multirow[t]{2}{*}{2} & SGD (Lv) & Constant & 4 & -1.19 & 0.677 & Constant & 5 & -3.60 & 0.008 & \multirow[t]{2}{*}{ I(1) } \\
\hline & $S G D(1 d)$ & None & 3 & -10.32 & 0.000 & Trend & 18 & -8.48 & 0.000 & \\
\hline \multirow[t]{2}{*}{3} & PHP (Lv) & Trend & 1 & -2.76 & 0.216 & Constant & 1 & -2.47 & 0.125 & \multirow[t]{2}{*}{ I(1) } \\
\hline & $\operatorname{PHP}(1 d)$ & Constant & 0 & -7.60 & 0.000 & Constant & 6 & -7.46 & 0.000 & \\
\hline \multirow[t]{2}{*}{4} & THB (Lv) & Constant & 5 & -2.05 & 0.266 & Constant & 4 & -3.21 & 0.022 & \multirow[t]{2}{*}{ I(1) } \\
\hline & THB (1d) & None & 4 & -4.13 & 0.000 & None & 22 & -7.33 & 0.000 & \\
\hline \multirow[t]{2}{*}{5} & JPY (LV) & Constant & 5 & -1.54 & 0.507 & Constant & 4 & -2.00 & 0.284 & \multirow{2}{*}{ I(1) } \\
\hline & JPY (1d) & None & 4 & -5.58 & 0.000 & None & 3 & -7.44 & 0.000 & \\
\hline
\end{tabular}

Pengujian terhadap sifat stasionaritas dari variabel eksogen juga menunjukkan bahwa variabel-variabel ini adalah I(1). First differencing telah cukup untuk mengubah sifat data menjadi stasioner (lihat tabel IV.4).

Dengan sifat data yang seperti ini, dimana variabel endogen adalah I(1) dan variabel eksogen (first difference form) adalah stasioner, maka penggunaan teknik VECM telah memenuhi persyaratan pertamanya. Disini semua variabel telah memiliki derajat integrasi yang sama. Tahap analisis selanjutnya dilakukan dengan pemilihan lag optimal.

Seperti juga uji unit root, lag optimal dipilih dengan terlebih dahulu memilih lag maksimum yang diperkirakan tidak lagi memiliki sifat autokorelasi. Kembali disini digunakan formula dari Said-Dickey (1984), yang memberikan lag maksimum sebanyak 5 (lihat tabel IV.5). Perhitungan kriteria informasi bagi setiap model OCA (bivariat dan model lengkap) menunjukkan lag optimal adalah pada lag ke 5. Pengecualian ada pada bivariat IDR-PHP, yang memberikan preferensi berimbang antara lag ke 4 dan ke 5. Disamping memenuhi syarat optimal, VAR dengan lag terpilih juga memenuhi syarat stabilitas.

Lag yang diperoleh sebelumnya akan digunakan sebagai lag terpilih didalam pengujian kointegrasi. Prosedur pengujian kointegrasi dilakukan dengan menggunakan teknik Johansen (1988) yang merupakan uji kointegrasi berbasis VAR. Teknik ini mengunakan reduced rank untuk menentukan jumlah persamaan kointegrasi yang ada pada variabel yang dianalisis. 


\begin{tabular}{|c|c|c|c|c|c|c|c|c|c|c|}
\hline \multirow{3}{*}{ No. } & \multirow{3}{*}{ Variabel } & \multicolumn{8}{|c|}{$\begin{array}{l}\text { Table IV.4 } \\
\text { ategrasi Terhadap Variabel Eksogen }\end{array}$} & \multirow{3}{*}{ Kesimpulan } \\
\hline & & \multicolumn{4}{|c|}{ ADF } & \multicolumn{4}{|c|}{ Phillips-Perron } & \\
\hline & & Model & Lag & t stat & $p$ value & Model & Bandwidth & t stat & $p$ value & \\
\hline \multirow[t]{8}{*}{1} & IDUS_INF (LV) & Constant & 4 & -3.75 & 0.00 & Constant & 9 & -3.92 & 0.00 & $I(0)$ \\
\hline & IDUS_INF(1d) & Constant & 3 & -12.15 & 0.00 & Constant & 65 & -22.40 & 0.00 & \\
\hline & SGUS_INF (Lv) & Constant & 1 & -9.65 & 0.00 & Constant & 4 & -13.14 & 0.00 & $I(0)$ \\
\hline & SGUS_INF (1d) & Constant & 5 & -8.32 & 0.00 & Constant & 18 & -46.67 & 0.00 & \\
\hline & PHUS_INF (LV) & Constant & 0 & -7.56 & 0.00 & Constant & 4 & -7.52 & 0.00 & $I(0)$ \\
\hline & PHUS_INF (1d) & Constant & 5 & -7.40 & 0.00 & Constant & 50 & -43.70 & 0.00 & \\
\hline & THUS_INF (LV) & Constant & 2 & -4.05 & 0.00 & Constant & 2 & -7.14 & 0.00 & $I(0)$ \\
\hline & THUS_INF (1d) & Constant & 5 & -6.67 & 0.00 & Constant & 54 & -29.47 & 0.00 & \\
\hline \multirow[t]{8}{*}{2} & IDUS_IRT(Lv) & Constant & 0 & -4.09 & 0.00 & Constant & 1 & -4.05 & 0.00 & $I(0)$ \\
\hline & IDUS_IRT(1d) & Constant & 1 & -9.57 & 0.00 & Constant & 9 & -13.09 & 0.00 & \\
\hline & SGUS_IRT (LV) & Constant & 0 & -6.46 & 0.00 & Constant & 2 & -6.47 & 0.00 & $I(0)$ \\
\hline & SGUS_IRT(1d) & Constant & 5 & -6.55 & 0.00 & Constant & 20 & -27.68 & 0.00 & \\
\hline & PHUS_IRT(LV) & Constant & 1 & -5.86 & 0.00 & Constant & 4 & -9.68 & 0.00 & $I(0)$ \\
\hline & PHUS_IRT(1d) & Constant & 3 & -7.65 & 0.00 & Constant & 15 & -42.68 & 0.00 & \\
\hline & THUS_IRT(LV) & Constant & 1 & -4.76 & 0.00 & Constant & 4 & -7.45 & 0.00 & $I(0)$ \\
\hline & THUS_IRT(1d) & Constant & 4 & -6.76 & 0.00 & Constant & 15 & -27.75 & 0.00 & \\
\hline \multirow[t]{8}{*}{3} & IDUS_GRW(LV) & Constant & 3 & -3.10 & 0.03 & Constant & 94 & -5.32 & 0.00 & $I(0)$ \\
\hline & IDUS_GRW(1d) & Constant & 5 & -8.23 & 0.00 & Constant & 20 & -20.36 & 0.00 & \\
\hline & SGUS_GRW (LV) & Constant & 5 & -5.50 & 0.00 & Constant & 10 & -10.07 & 0.00 & $I(0)$ \\
\hline & SGUS_GRW(1d) & Constant & 5 & -7.64 & 0.00 & Constant & 41 & -14.77 & 0.00 & \\
\hline & PHUS_GRW(LV) & Constant & 5 & -5.40 & 0.00 & Constant & 32 & -7.26 & 0.00 & $I(0)$ \\
\hline & PHUS_GRW(1d) & Constant & 2 & -18.94 & 0.00 & Constant & 20 & -20.52 & 0.00 & \\
\hline & THUS_GRW(LV) & Constant & 5 & -10.83 & 0.00 & Constant & 1 & -4.51 & 0.00 & $I(0)$ \\
\hline & THUS_GRW(1d) & Constant & 5 & -10.91 & 0.00 & Constant & 2 & -10.66 & 0.00 & \\
\hline \multirow[t]{8}{*}{4} & IDUS_M1C(Lv) & Constant & 0 & -9.99 & 0.00 & Constant & 2 & -9.99 & 0.00 & $I(0)$ \\
\hline & IDUS_M1C(1d) & Constant & 4 & -7.86 & 0.00 & Constant & 57 & -80.84 & 0.00 & \\
\hline & SGUS_M1C (LV) & Constant & 0 & -12.47 & 0.00 & Constant & 2 & -12.59 & 0.00 & $I(0)$ \\
\hline & SGUS_M1C(1d) & Constant & 4 & -7.41 & 0.00 & Constant & 23 & -63.37 & 0.00 & \\
\hline & PHUS_M1C(Lv) & Constant & 0 & -10.18 & 0.00 & Constant & 6 & -10.32 & 0.00 & $I(0)$ \\
\hline & PHUS_M1C(1d) & Constant & 5 & -7.10 & 0.00 & Constant & 31 & -56.06 & 0.00 & \\
\hline & THUS_M1C(LV) & Constant & 3 & -4.19 & 0.00 & Constant & 5 & -9.14 & 0.00 & $I(0)$ \\
\hline & THUS_M1C(1d) & Constant & 1 & -12.44 & 0.00 & Constant & 3 & -21.74 & 0.00 & \\
\hline
\end{tabular}

Hasil pengujian kointegrasi sensitif terhadap komponen deterministik yang diasumsikan pada model (Johansen, 1995). Terdapat 5 jenis model dengan komponen deterministik yang dipertimbangkan, yakni13:

1. Data tidak memiliki trend deterministik dan persamaan kointegrasi tidak memiliki intersep.

2. Data tidak memiliki trend deterministik dan persamaan kointegrasi memiliki intersep.

3. Data memiliki trend linier dan persamaan kointegrasi hanya memiliki intersep.

4. Data dan persamaan kointegrasi memiliki trend linier.

5. Data memiliki trend kuadratik dan persamaan kointegrasi memiliki trend linier.

13 Model terbaik yang dianggap mencerminkan persamaan kointegrasi akan dilihat dari nilai kriteria informasi (digunakan AIC dan SIC). Model yang terpilih adalah model dengan nilai kriteria informasi terendah pada lag kointegrasi. 


\begin{tabular}{|c|c|c|c|c|}
\hline & Pem & $\begin{array}{l}\text { Table I } \\
\text { ag Optimal }\end{array}$ & $\begin{array}{l}.5 \\
\text { an Syarat Stab }\end{array}$ & \\
\hline No. & Tipe OCA & Lag Optimal & Kriteria & Stabilitas \\
\hline 1 & IDR-SGD & 5 & LR, FPE, AIC, HQ & Ya \\
\hline 2 & IDR-PHP & $\begin{array}{l}5 \\
4\end{array}$ & $\begin{array}{l}\text { FPE, AIC } \\
L R, H Q\end{array}$ & Ya \\
\hline 3 & IDR-THB & 5 & LR, FPE, AIC, HQ & Ya \\
\hline 4 & SGD-PHP & 5 & LR, FPE, AIC, HQ & Ya \\
\hline 5 & SGD-THB & 5 & $L R, F P E, A I C, H Q$ & Ya \\
\hline 6 & PHP-THB & 5 & LR, FPE, AIC & Ya \\
\hline 7 & Model Lengkap & 5 & $L R, F P E, A I C$ & Ya \\
\hline
\end{tabular}

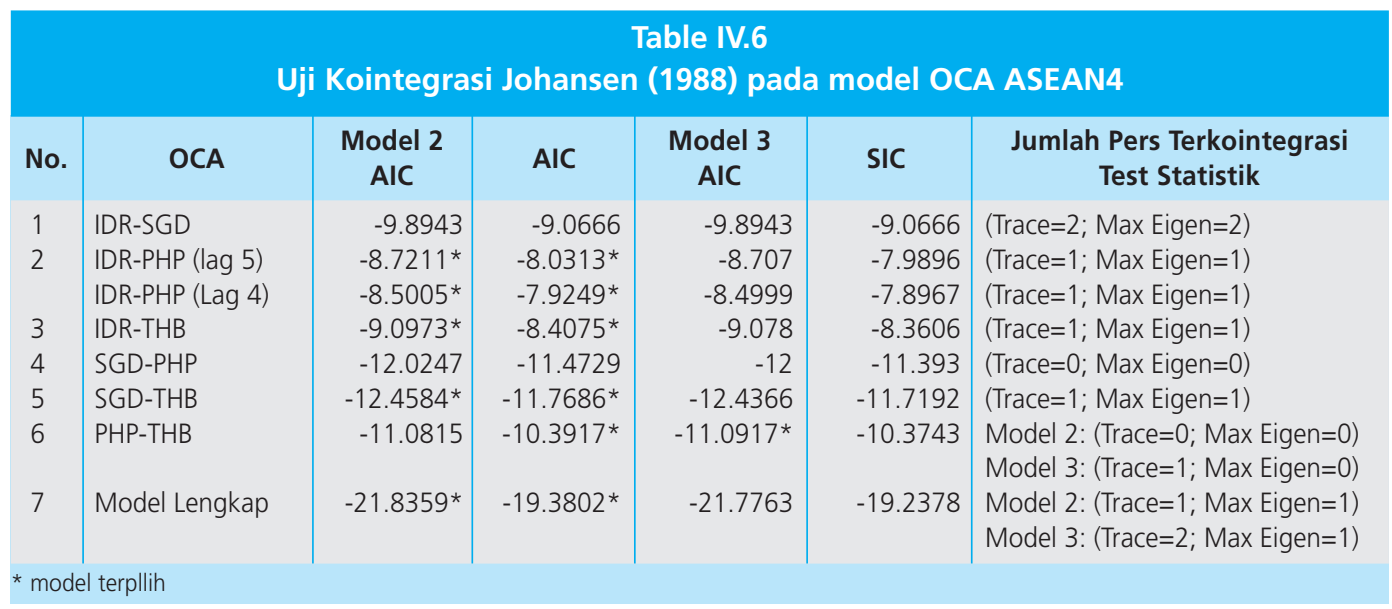

Seperti yang dapat dilihat pada tabel IV.6, kecuali pada bivariat SGD-PHP, uji kointegrasi Johansen (1988) menunjukkan hasil yang signifikan. Disini paling tidak terdapat satu persamaan terkointegrasi pada bivariate: IDR-PHP, IDR-THB, SGD-THB dan model lengkap. Uji kointegrasi memberikan hasil yang lemah untuk pasangan PHP-THB dan negatif untuk SGD-PHP. Sedangkan untuk model lengkap, pengujian secara konklusif menunjukkan paling tidak terdapat satu persamaan kointegrasi.

Hasil ini memberikan indikasi awal dukungan bagi hipotesis adanya OCA diwilayah ASEAN 4. Meskipun demikian kesimpulan yang lebih tegas masih harus diperoleh melalui keberadaan mekanisme error correction yang signifikan.

Kecuali bivariat PHP-THB, semua model OCA bivariat memiliki tingkat model goodness of fit $\left(R^{2}\right)$ yang moderat ( $0.5 \mathrm{~s} / \mathrm{d}$ 0.65) (lihat tabel IV.7). Tingkat goodness of fit yang tertinggi dimiliki oleh bivariat IDR-THB sebesar 0.66. Yang terendah dimiliki oleh IDR-PHP (lag 4), dengan nilai $R^{2}$ sebesar 0.58. Disini variabel independen secara bersama menjelaskan $50 \%-65 \%$ variasi yang terjadi pada variabel dependen. OCA model lengkap memiliki goodness of fit yang lebih 


\begin{tabular}{|c|c|c|c|c|c|}
\hline & & $\begin{array}{l}\text { Tabl } \\
\text { ss of }\end{array}$ & del $O$ & & \\
\hline No. & Tipe OCA & $\mathbf{R}^{2}$ & F Stat & AIC & SIC \\
\hline 1 & IDR-SGD & 0.61 & 5.88 & -2.90 & -2.34 \\
\hline 2 & IDR-PHP (lag 4) & 0.58 & 6.01 & -2.87 & -2.37 \\
\hline 3 & IDR-PHP (Lag 5) & 0.65 & 6.98 & -3.01 & -2.45 \\
\hline 4 & IDR-THB & 0.66 & 7.11 & -3.02 & -2.47 \\
\hline 5 & SGD-PHP & 0.64 & 6.69 & -6.43 & -5.88 \\
\hline 6 & SGD-THB & 0.64 & 6.27 & -6.41 & -5.83 \\
\hline 7 & PHP-THB & 0.34 & 1.93 & -5.14 & -4.59 \\
\hline 8 & Model Lengkap & 0.78 & 5.22 & -3.10 & -2.05 \\
\hline
\end{tabular}

tinggi dari model bivariat. Disini nilai $\mathrm{R}^{2}$ adalah sebesar 0.78 , secara signifikan diatas seluruh nilai OCA bivariat.

\section{IV.2. Co-Movement Mata Uang ASEAN dan Faktor Penentunya}

Dari tabel IV.8 terlihat bahwa hanya 14 dari 88 (16\%) koefisien yang diestimasi lulus dari uji signifikansi parsial pada $a=5 \%$. Hal ini merupakan indikasi awal dari lemahnya dukungan data terhadap keberadaan co-movement yang berarti secara statistik.

Tanda aljabar pada koefisien co-movement jangka pendek tidak homogen. Keadaan seperti ini tidak sejalan dengan hipotesis, dimana dalam jangka pendek sekalipun diharapkan agar mata uang bergerak searah (dan dengan demikian memiliki koefisien yang positif). Pada

\begin{tabular}{|c|c|c|c|c|c|c|c|c|c|c|c|}
\hline & Koefis & n Co-m & lovemer & nt Jangl & $\begin{array}{l}\text { Table IV. } \\
\text { ka Pend }\end{array}$ & ek ( $t$ s & tistik c & didalam & kurung & & \\
\hline No. & Tipe OCA & $\mathrm{D}(\mathrm{IDR}(-1))$ & $D(I D R(-2))$ & $D(I D R(-3))$ & $D(I D R(-4))$ & D(IDR(-5)) & $\mathrm{D}(\mathrm{SGD}(-1))$ & $D(S G D(-2))$ & $D(S G D(-3))$ & $D(S G D(-4))$ & $D(S G D(-5))$ \\
\hline 1 & IDR-SGD (D(IDR)) & 0.1428 & 0.0665 & -0.0773 & 0.0498 & 0.0941 & -0.0972 & -0.5629 & -0.8789 & -0.9344 & -0.0633 \\
\hline & & [1.1984] & {$[0.6947]$} & {$[-0.8249]$} & {$[0.5871]$} & [1.0926] & {$[-0.1732]$} & {$[-0.9954]$} & {$[-1.5325]$} & {$[-1.683]$} & {$[-0.1147]$} \\
\hline 2 & IDR-PHP Lag 4 (D(IDR)) & 0.0113 & -0.0334 & -0.0467 & 0.0742 & - & - & - & & - & - \\
\hline & & {$[0.1175]$} & {$[-0.3939]$} & {$[-0.5454]$} & {$[0.9585]$} & & - & - & & - & - \\
\hline & IDR-PHP Lag 5 (D(IDR)) & 0.1507 & 0.0432 & -0.0704 & 0.1024 & 0.0348 & - & - & - & - & - \\
\hline & & {$[1.5137]$} & {$[0.5014]$} & {$[-0.8708]$} & [1.3892] & [0.4682] & - & - & - & - & - \\
\hline 3 & IDR-THB (D(IDR)) & 0.1581 & -0.0739 & -0.0666 & 0.1451 & -0.156 & - & - & - & - & - \\
\hline & & [1.4844] & {$[-0.6798]$} & {$[-0.6667]$} & [1.5273] & {$[-1.6545]$} & - & - & - & - & - \\
\hline 4 & SGD-PHP (D(SGD)) & - & - & & - & - & 0.01789 & -0.1392 & -0.0645 & -0.0597 & -0.0325 \\
\hline & & & & & & - & [0.2002] & {$[-1.5561]$} & {$[0.0862]$} & {$[-0.7334]$} & {$[-0.3881]$} \\
\hline 5 & SGD-THB (D(SGD)) & - & - & - & - & - & 0.112 & -0.3001 & -0.0032 & 0.0957 & 0.0749 \\
\hline & & - & & & - & - & [1.0325] & {$[-2.7131]$} & {$[-0.0286]$} & [0.8865] & {$[0.6837]$} \\
\hline 6 & PHP-THB (D(PHP)) & - & - & - & - & - & - & - & & - & - \\
\hline & & & & & - & - & - & - & - & - & - \\
\hline 7 & Model Lengkap (D(IDR)) & 0.1988 & -0.1137 & -0.0832 & 0.1157 & -0.1942 & -0.0593 & -0.501 & 0.0378 & 1.4449 & 0.3633 \\
\hline & & [1.6803] & {$[-0.9705]$} & {$[-0.7294]$} & {$[1.0400]$} & {$[-1.7041]$} & {$[-0.0743]$} & {$[-0.6792]$} & {$[0.0453]$} & [2.0682] & [0.5058] \\
\hline
\end{tabular}




\begin{tabular}{|c|c|c|c|c|c|c|c|c|c|c|c|}
\hline & Koefis & Co-n & veme & $\begin{array}{l}\text { Table } \\
\text { nt Jan }\end{array}$ & a Per & $\begin{array}{l}\text { utan) } \\
\text { k (t st }\end{array}$ & atistik & didalam & kurur & & \\
\hline No. & Tipe OCA & $\mathrm{D}(\mathrm{PHP}(-1))$ & $\mathrm{D}(\mathrm{PHP}(-2))$ & $D(P H P(-3))$ & D(PHP(-4)) & $D(P H P(-5))$ & $D(T H B(-1))$ & $D(T H B(-2))$ & $D(T H B(-3))$ & $D(T H B(-4))$ & $\mathrm{D}(\mathrm{THB}(-5))$ \\
\hline 1 & IDR-SGD (D(IDR)) & - & - & & & - & & - & & - & - \\
\hline & & & & & & - & - & - & & - & - \\
\hline 2 & IDR-PHP Lag 4 (D(IDR)) & -0.5431 & -0.1261 & -0.8632 & -0.7693 & - & - & - & & - & - \\
\hline & & {$[-1.5639]$} & {$[-0.3781]$} & {$[-2.6815]$} & {$[-2.2665]$} & - & - & - & & - & - \\
\hline & IDR-PHP lag 5 (D(IDR)) & -0.165 & -0.2186 & -0.6699 & -0.7491 & 0.6855 & - & - & - & - & - \\
\hline & & {$[-0.4867]$} & {$[-0.6500]$} & {$[-2.1834]$} & {$[-2.3654]$} & [1.9922] & - & - & & & - \\
\hline 3 & IDR-THB (D(IDR)) & & & & - & - & -0.0395 & 0.4991 & -0.5733 & -0.7511 & 0.8182 \\
\hline & & & & & & - & {$[-0.1214]$} & {$[1.4577]$} & {$[-2.2427]$} & {$[-2.9383]$} & [2.8642] \\
\hline 4 & SGD-PHP (D(SGD)) & 0.01923 & -0.1092 & -0.0829 & -0.0472 & 0.0061 & - & - & & - & \\
\hline & & {$[0.3021]$} & {$[-1.9025]$} & [-1.4239] & {$[-0.8419]$} & {$[0.1082]$} & - & - & & - & - \\
\hline 5 & SGD-THB (D(SGD)) & & & & & - & -0.0468 & 0.0318 & -0.1081 & -0.1165 & -0.0414 \\
\hline & & & & & & & {$[-0.8009]$} & {$[0.5850]$} & {$[-2.0400]$} & {$[-2.2324]$} & {$[-0.7796]$} \\
\hline 6 & PHP-THB (D(PHP)) & 0.3174 & -0.0943 & 0.0013 & -0.1457 & 0.1712 & 0.1194 & -0.0211 & -0.0369 & 0.1093 & -0.1213 \\
\hline & & [2.4877] & ]$[-0.7277]$ & [0.0098] & {$[-1.1328]$} & [1.3600] & {$[1.085]$} & {$[-0.2225]$} & {$[-0.4090]$} & [1.2422] & {$[-1.4219]$} \\
\hline 7 & Model Lengkap (D(IDR)) & -0.7742 & -0.2095 & -0.2714 & -0.5506 & 0.08764 & 0.4888 & 0.7178 & -0.4772 & -1.0004 & 0.6205 \\
\hline & & {$[-1.7848]$} & {$[-0.5340]$} & {$[-0.6612]$} & {$[-1.3721]$} & {$[0.2174]$} & {$[1.0032]$} & [1.5312] & {$[-1.1365]$} & {$[-2.6631]$} & [1.4401] \\
\hline
\end{tabular}

beberapa bivariate tertentu koefisien-koefisien co-movement jangka pendek yang signifikan justru bernilai negatif (lihat misalnya OCA IDR-PHP lag 5 koefisien D(PHP(-3)) yang bernilai 0.6699) .

Kecenderungan yang disebutkan diatas berlaku baik pada OCA bivariate maupun OCA model lengkap. Dengan demikian dapat dikatakan estimasi bagi persamaan jangka pendek tidak mendukung adanya co-movement.

Dari tabel IV.9. keberadaan mekanisme penyesuaian (error correction term) pada bivariat SGD-THB dan PHP-THB tidak memperoleh dukungan data. Hal ini terlihat dari rendahnya statistik $t$ koefisien error correction/cointegrating term yang bernilai hanya (masing-masing) - 0.5004 dan -1.2001 yang jauh dibawah $t$ kritis pada level of significance yang standar ( $5 \%$ dan/atau $1 \%)$. Hasil ini agak bertentangan dengan hasil pengujian kointegrasi yang menunjukkan paling tidak ada 1 (satu) persamaan terkointegrasi (lihat tabel IV.6).

Disisi lain hasil estimasi bivariat SGD-PHP adalah tidak konsisten dengan uji kointegrasi. Nilai koefisien kointegrasi yang negatif dan signifikan bertentangan dengan hasil uji kointegrasi (statistik Trace dan Max-Eigen) yang meunjukkan 0 (nol) hubungan kointegrasi.

Paper ini menggunakan pendekatan yang agak konservatif. Hasil yang cenderung kontradiktif pada tiga bivariat diatas mendorong penulis untuk mengambil kesimpulan tidak adanya hubungan ekuilibrium pada bivariat mata uang Singapura - Thailand (SGD-THB), Singapura - Philipina (SGD-PHP) dan Philipina-Thailand (PHP-THB). 


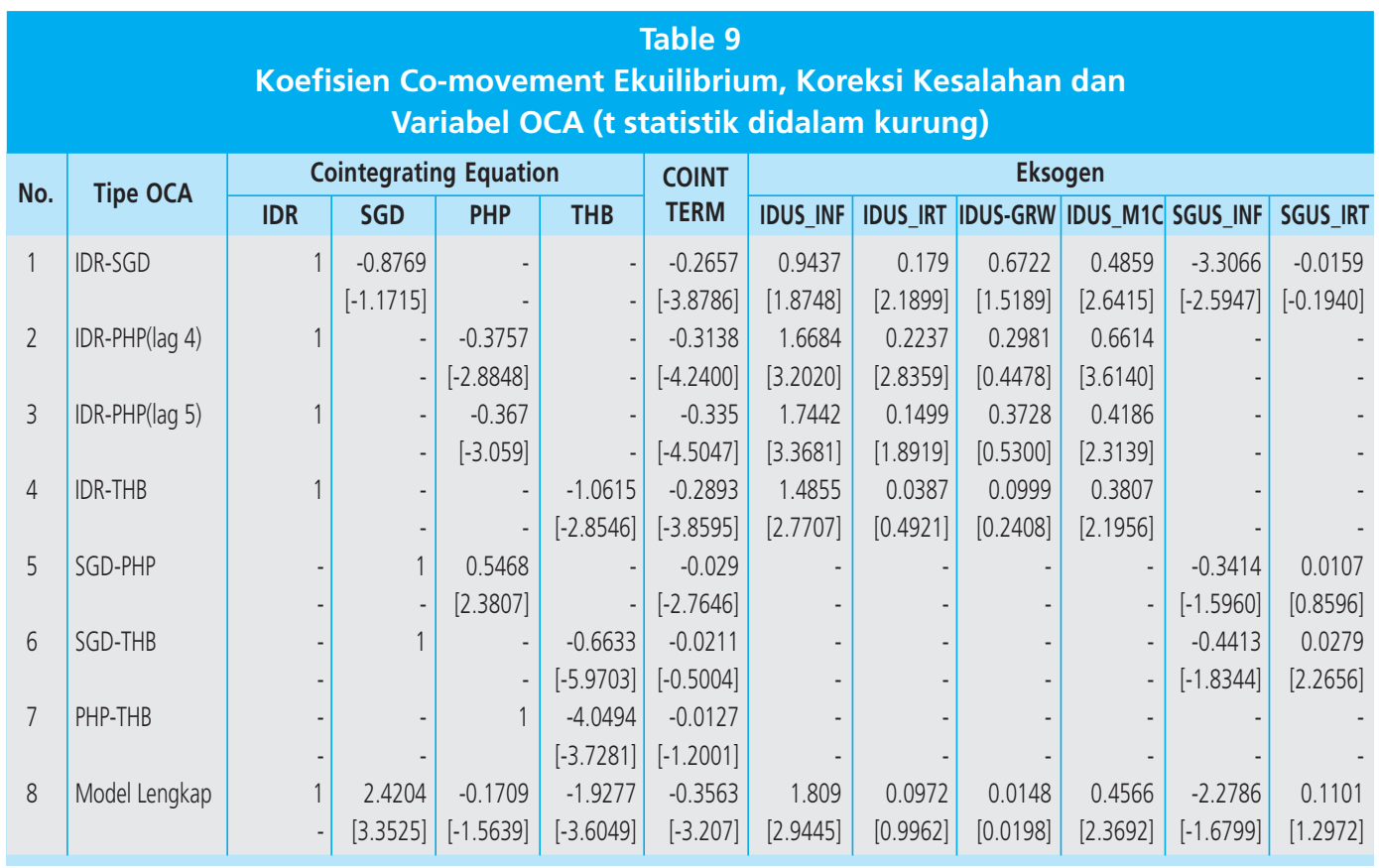

Lanjutan

\begin{tabular}{|c|c|c|c|c|c|c|c|c|c|c|c|c|}
\hline \multirow{2}{*}{ No. } & \multirow{2}{*}{ Tipe OCA } & \multicolumn{11}{|c|}{ Eksogen } \\
\hline & & SGUS-GRW & SGUS_MIC & PHUS_INF & PHUS_IRT & PHUS-GRW & PHUS_M1C & THUS_INF & THUS_IRT & THUS-GRW & THUS_MIC & JPY_FX \\
\hline \multirow[t]{2}{*}{1} & IDR-SGD & 0.4466 & -0.4181 & & & & & & & - & & 0.4946 \\
\hline & & [0.7320] & {$[-1.7001]$} & & & & & & & & & {$[1.9843$} \\
\hline \multirow[t]{2}{*}{2} & IDR-PHP(lag 4) & & & -0.82 & 0.0395 & 0.1102 & -0.1086 & & - & - & & 0.5607 \\
\hline & & & & {$[-0.8346]$} & [0.9461] & [0.4719] & {$[-0.5656]$} & & & & & {$[2.2329$} \\
\hline \multirow[t]{2}{*}{3} & IDR-PHP(lag 5) & & & -1.2067 & 0.0262 & 0.1582 & -0.0649 & & & & & 0.383 \\
\hline & & & & {$[-1.2934]$} & [0.6744] & [0.6696] & {$[-0.3472]$} & & & & & {$[1.5815$} \\
\hline \multirow[t]{2}{*}{4} & IDR-THB & & & & & & & 0.5465 & -0.0015 & -0.4884 & -0.0389 & 0.3524 \\
\hline & & & & & & & & [0.3569] & {$[-0.0221]$} & {$[-1.346]$} & {$[-0.2507]$} & {$[1.4925$} \\
\hline \multirow[t]{2}{*}{5} & SGD-PHP & -0.0597 & 0.0211 & 0.0143 & 0.0133 & 0.0422 & 0.0115 & & & & & 0.2945 \\
\hline & & {$[-0.4695]$} & [0.4958] & [0.0883] & [1.9096] & [1.3503] & [0.3610] & & & & & {$[7.2381$} \\
\hline \multirow[t]{2}{*}{6} & SGD-THB & 0.0106 & 0.0168 & & & & & 0.0859 & -0.0128 & -0.0047 & 0.0426 & 0.3036 \\
\hline & & [0.1023] & [0.3844] & & & & & {$[0.2659]$} & {$[-1.1746]$} & {$[-0.0774]$} & [1.5405] & {$[6.7928$} \\
\hline \multirow[t]{2}{*}{7} & PHP-THB & & & 0.1266 & 0.0063 & 0.0147 & -0.0084 & -0.5296 & -0.0033 & 0.0811 & 0.0803 & 0.2097 \\
\hline & & & & [0.4384] & [0.4638] & [0.2925] & {$[-0.1263]$} & {$[-1.0422]$} & {$[-0.1685]$} & [0.6795] & [1.3817] & {$[2.7799$} \\
\hline \multirow[t]{2}{*}{8} & Model Lengkap & 0.5088 & -0.6607 & -0.6794 & {$[0.0719]$} & -0.2894 & 0.1887 & 1.1167 & -0.1289 & -0.1309 & -0.1979 & 0.3006 \\
\hline & & [0.6473] & {$[-2.4424]$} & {$[-0.6773]$} & {$[1.728]$} & {$[-0.9515]$} & [0.9499] & [0.5940] & [-1.7411] & {$[-0.3052]$} & {$[-0.1709]$} & {$[1.1183$} \\
\hline
\end{tabular}

Sedangkan untuk bivariat yang lainnya yakni pasangan mata uang Indonesia-Singapura (IDR-SGD), Indonesia-Philipina (IDR-PHP) dan Indonesia-Thailand (IDR-THB) serta model lengkap, kita dapat menerima hipotesis adanya co-movement yang berarti. Untuk model-model ini, koefisien kointegrasi telah sesuai dengan hipotesis dan signifikan pada level standar. Dengan demikian untuk pasangan mata uang ini, representasi error correction dapat dikatakan valid. 
Umumnya koefisien persamaan ekuilibrium yang diperoleh dari estimasi OCA bivariat telah memenuhi hipotesis (koefisien persamaan ekuilibrium adalah positif). Terdapat pengecualian pada bivariat SGD-PHP dimana koefisien yang diperoleh justru negatif, dalam hal ini SGD = -0.5468 PHP. Dengan kata lain nilai tukar SGD (terhadap USD) adalah turun (menguat) ketika PHP meningkat (melemah). Hal ini berbeda dengan hipotesis yang mengharapkan hubungan dengan tanda koefisien yang sama. Sedangkan untuk bivariat IDR-SGD, koefisien hubungan jangka panjang tidak signifikan.

Magnitude OCA bivariat cukup bervariasi. IDR-THB misalnya nyaris berkorespondensi satu-satu. Satu persen kenaikan (penurunan) nilai tukar IDR akan diikuti pula oleh satu persen kenaikan (penurunan) nilai THB. Respon terbesar diberikan oleh bivariat PHP-THB sebesar 4.0494 sedangkan yang terkecil adalah IDR-PHP sebesar 0.3737.

Pada OCA model lengkap hasil yang diperoleh tidak sesuai dengan hipotesis. Disini tanda koefisien PHP dan THB adalah positif (yakni 0.17 dan 1.93), namun demikian koefisien PHP tidak signifikan pada level standar. Sedangkan koefisien SGD justru memiliki tanda yang berlawanan dengan hipotesis. Dengan memperhitungkan PHP dan THB, 1\% kenaikan (pelemahan) SGD terhadap USD diikuti dengan penguatan IDR sebesar $2.42 \%$.

Pada OCA bivariat dimana IDR merupakan variabel tergantung, umumnya tanda koefisien variabel kontrol sendiri ${ }^{4}$ telah sesuai dengan hipotesis dan memiliki tingkat signifikansi yang memadai. Sebagai contoh OCA bivariat IDR-SGD, baik variabel selisih suku bunga dan jumlah uang beredar (terhadap US) memiliki pegaruh yang positif terhadap nilai tukar dan signifikan pada _ yang standar. Variabel kontrol lain pada OCA bivariat ini memiliki koefisien yang sesuai hipotesis meskipun tingkat signifikansi yang harus digunakan adalah agresif (>10\%). Pengecualian ada pada variabel selisih pertumbuhan, dimana tidak ada satupun OCA bivariat dimana variabel ini adalah signifikan.

Pada OCA bivariat lainnya, beberapa koefisien variabel kontrol sendiri memiliki tanda yang salah (lihat misalnya variabel SGUS_INF pada OCA bivariat SGD-PHP dan PHPUS_M1C pada OCA bivariat PHP-THB). Signifikansi koefisien umumnya tidak memadai. Hal ini dapat dilihat misalnya pada OCA bivariat SGD-PHP, dimana tidak satupun variabel kontrol sendiri dapat dikatakan signifikan pada level standar. Satu-satunya OCA bivariat diluar IDR yang memiliki koefisien variabel kontrol sendiri yang signifikan adalah SGD-THB (yakni SGUS_IRT).

\footnotetext{
14 Yang dimaksud dengan variabel kontrol sendiri adalah variabel eksogen (yang diturunkan dari teori pendekatan moneter) yang terkait dengan variabel tergantung pada hubungan ekuilibrium (persamaan terkointegrasi). Sebagai contoh variabel kontrol sendiri pada OCA bivariat IDR-SGD adalah seluruh variabel eksogen IDUS_X dimana $X$ adalah tingkat inflasi (INF), suku bunga (IRT), pertumbuhan (GRW) dan jumlah uang beredar (M1C).
} 
Tanda koefisien dari variabel kontrol asing ${ }^{15}$ secara umum adalah tidak konsisten dengan hipotesis. Pada beberapa OCA bivariat dan variabel tertentu tanda telah sesuai dengan hipotesis, lihat misalnya THUS_INF pada OCA IDR-THB. Disisi yang lain tanda variabel justru berlawanan dengan hipotesis, ini terjadi misalnya pada OCA bivariat SGD-THB (variabel THUS_IRT). Disamping itu persyaratan signifikansi koefisien variabel kontrol asing umumnya tidak tercapai (pada level standar). Suatu pengecualian adalah pada variabel SGUS_INF pada OCA bivariat IDR-SGD yang signifikan pada _ $=5 \%$.

Pada model lengkap, dimana IDR adalah variabel dependen pada persamaan ekuilibrium, variabel kontrol sendiri: IDUS_INF dan IDUS_M1C, telah memiliki tanda yang sesuai dengan hipotesis dan signifikan pada level standar (masing-masing 1\% dan 5\%). Variabel lain (IDUS_IRT dan IDUS_GRW) juga memiliki tanda yang telah sesuai dengan hipotesis tetapi tidak signifikan.

Sedangkan tanda variabel kontrol asing adalah tidak konsisten dengan hipotesis. Pada beberapa variabel misalnya PHUS_M1C dan THUS_INF, dampak perubahan telah sesuai dengan yang diharapkan. Namun hal sebaliknya terjadi pada beberapa variabel lain, misalnya SGUS_M1C dan THUS_M1C yang kontradiksi dengan hipotesis. Disini kecuali variabel SGUS_M1C, variabel kontrol asing adalah tidak signifikan pada $\ldots=5 \%$.

Tanda koefisien variabel eksogen nilai tukar JPY (terhadap USD) adalah positif pada semua OCA bivariat. Hal ini telah sesuai dengan hipotesis. Pada beberapa OCA bivariat (IDR-SGD, IDRPHP(lag=4), SGD-PHP, SGD-THB dan PHP-THB, koefisien yang diperoleh adalah signifikan pada _ yang standar (5\%). Sedangkan pada OCA bivariat IDR-PHP (lag=5) dan IDR-THB, variabel eksogen JPY tampaknya tidak memiliki pengaruh penjelas yang signifikan.

Respon terbesar dari perubahan JPY dimiliki oleh bivariat IDR-PHP (sebesar 0.5607), sedangkan yang terkecil (dengan tetap memperhatikan signifikansi koefisien) dimiliki oleh bivariat PHP-THB (sebesar 0.2097).

Pada OCA model lengkap, dampak JPY adalah konsisten dengan OCA dilevel bivariat. Namun demikian variabel JPY pada OCA model lengkap adalah tidak signifikan. Dengan demikian dapat dikatakan dengan mempertimbangkan seluruh co-movement, tidak ada alasan untuk menerima bahwa hubungan ekuilibrium dapat dijelaskan oleh pergerakan JPY.

\footnotetext{
15 Variabel kontrol asing adalah variabel eksogen yang terkait dengan variabel bebas yang terletak pada sisi sebelah kanan persamaan terkointegrasi. Pada OCA bivariat IDR-SGD, variabel ini adalah seluruh variabel eksogen SGUS_X dimana X adalah tingkat inflasi (INF), suku bunga (IRT), pertumbuhan (GRW) dan jumlah uang beredar (M1C).
} 


\section{IV.3. Eksistensi OCA dan Assessment Persayaratannya}

Dari hasil estimasi VECM maupun uji kointegrasi yang telah dilaporkan diatas tampaknya suatu co-movement dalam bentuk yang kuat diwilayah Asia Tenggara tidak dapat didukung oleh data. Hal ini terlihat dari (1) lemahnya signifikansi dari koefisien-koefisien co-movement persamaan jangka pendek dan (2) divergennya hasil estimasi error correction term dan koefisien co-movement jangka panjang.

Lemahnya signifikansi koefisien persamaan jangka pendek menunjukkan rendahnya kemampuan interaksi diantara mata uang ASEAN 4 yang diamati. Namun demikan cukup mengherankan, disini koefisien error correction term ternyata memiliki kinerja yang relatif lebih baik. Intrepetasi ekonomi dari hal ini adalah bahwa meskipun interaksi antar mata uang ASEAN4 dalam jangka pendek adalah lemah (mereka bergerak secara independen), namun terdapat suatu mekanisme koreksi jika mereka berada diluar paritas.

Ditinjau dari persamaan jangka panjang, dugaan suatu co-movement pada mata uang ASEAN 4 memiliki dukungan data yang lebih kuat dibandingkan persamaan jangka pendek. Disini tingkat signifikansi yang cukup baik diperoleh bagi koefisien co-movement ekuilibrium bagi OCA bivariat: IDR-SGD, IDR-PHP, IDR-THB dan OCA lengkap. Sedangkan pada OCA bivariat: SGD-THB, PHP-THB dan SGD-PHP, keberadaan fenomena ini tidak memiliki signifikansi yang diperlukan.

Lebih lanjut dengan melihat OCA bivariat dimana IDR adalah variabel dependen, maka adanya co-movement bagi mata uang ASEAN 4 dengan mata uang jangkar USD adalah valid. Beberapa hubungan ekuilibrium yang dapat diuraikan untuk menjustifikasi hal ini adalah

a. IDR-SGD, setiap apresiasi/depresiasi sebesar 1\% pada SGD (terhadap USD) akan disertai dengan apresiasi/depresiasi sebesar $0.88 \%{ }^{16}$ pada IDR.

b. IDR-PHP, setiap apresiasi/depresiasi sebesar $1 \%$ pada PHP (terhadap USD) akan disertai dengan apresiasi/depresiasi sebesar $0.37 \%(\operatorname{lag} 5)-0.38 \%(\operatorname{lag} 4)$ pada IDR.

C. IDR-THB, setiap apresiasi/depresiasi sebesar 1\% pada THB (terhadap USD) akan disertai dengan apresiasi/depresiasi sebesar $1.06 \%$ pada IDR.

Pengembangan OCA bivariat lebih lanjut dengan memasukkan mata uang ASEAN 4 lainnya secara lengkap juga memberikan dukungan terhadap keberadaan co-movement nilai tukar. Untuk model lengkap intrepretasi parsial ${ }^{17}$ hubungan yang berlaku adalah apresiasi/ depresiasi pada PHP sebesar $1 \%$ akan disertai dengan apresiasi/depresiasi sebesar $0.17 \%$ pada

16 Namun demikian koefisien SGD pada persamaan ekuilibrium tidak signifikan.

17 Intrepretasi parsial khususnya berlaku terhadap suatu persamaan regresi bervariabel lebih dari dua. Dimaksud parsial adalah dampak yang hendak diamati terhadap variabel terikat adalah akibat perubahan satu variabel bebas dengan mengasumsikan variabel bebas lainnya adalah konstan. 
IDR. Sedangkan apresiasi/depresiasi THB sebesar 1\%, akan memberikan dampak sebesar 1.93\% pada apresiasi/depresiasi IDR. Suatu pengecualian ada pada SGD karena karena arah pergerakan yang dimilikinya adalah berlawanan (dan signifikan). Disini 1\% apresiasi/depresiasi SGD akan diikuti oleh depresiasi/apresiasi IDR sebesar $2.42 \%$.

Dari representasi error correction, dapat diturunkan lamanya proses penyesuaian terhadap disekuilibrium bagi setiap pasangan mata uang sebagai berikut:

1. IDR-SGD $=3.77$ bulan (setiap bulan terjadi penyesuaian sebesar $26.57 \%$ dari kondisi disekuilibrium)

2. IDR-PHP $(\operatorname{lag} 4)=3.19$ bulan (setiap bulan terjadi penyesuaian sebesar $31.38 \%$ dari kondisi disekuilibrium)

3. IDR-PHP $(\operatorname{lag} 5)=2.99$ bulan (setiap bulan terjadi penyesuaian sebesar $33.35 \%$ dari kondisi disekuilibrium)

4. IDR-THB $=3.46$ bulan (setiap bulan terjadi penyesuaian sebesar $28.93 \%$ dari kondisi disekuilibrium)

5. Model lengkap $=2.78$ bulan (setiap bulan terjadi penyesuaian sebesar $35.63 \%$ dari kondisi disekuilibrium)

Sekilas dari analisis ini terlihat kemungkinan adanya co-movement yang secara statistik signifikan di antara beberapa mata uang ASEAN4. Mata uang yang menjadi acuan adalah USD. Temuan ini mendukung hasil studi Frankel dan Wei (1994) yang menduga wilayah Asia adalah memiliki acuan terhadap USD. Orientasi penetapan nilai tukar yang cenderung pada USD ini kuat diduga dalam rangka mengendalikan inflasi (cost push inflation).

Lebih lanjut keberadaan co-movement ini juga dapat diduga dipengaruhi oleh mata uang diluar USD, dimana dalam paper ini diajukan alternatif JPY. Seperti yang dilaporkan pada bagian sebelumnya, keseragaman koefisien (serta cukup baiknya signifikansi) variabel JPY pada seluruh OCA (baik bivariat maupun lengkap) memperkuat dugaan ini. Positifnya hubungan antara mata uang ASEAN4 dengan JPY telah menyebabkan dugaan pergeseran hubungan antara negara diwilayah ini dengan Jepang menjadi rival (terutama dalam aspek perdagangan).

Implikasi lebih jauh adalah kemungkinan adanya nilai tukar jangkar berupa suatu keranjang mata uang, dimana baik USD maupun JPY adalah komponen dominan. Hal ini memperkuat temuan empiris yang dilakukan oleh Kim dan Ryou (2001). Peran dominan JPY ini sebenarnya telah terindikasi oleh Frankel pada suatu studinya di tahun 1992, dimana karena faktor ekonomi dan non ekonomi (agenda dari Washington) diperkirakan peran Jepang diwilayah Asia akan semakin meningkat. 
Sebagai suatu kesimpulan dapat dinyatakan disini bahwa keberadaan co-movement diantara mata uang ASEAN4 tidak didukung secara kuat oleh data. Hal ini disebabkan (1) lemahnya signifikansi pada koefisien co-movement jangka pendek dan (2) tidak homogennya tanda koefisien koreksi kesalahan dan co-movement jangka panjang. Namun demikian, studi ini telah mengungkapkan suatu kemungkinan bagi keberadaan OCA. Hal ini ditunjukkan oleh homogennya tanda koefisien JPY (dengan signifikansi yang moderat). Studi lebih lanjut dengan menggunakan suatu jangkar komposit mungkin dapat lebih baik mengungkapkan keberadaan OCA.

Beberapa hal yang diduga menyebabkan gagalnya variabel pendekatan moneter berperan sebagai variabel kontrol pada beberapa model OCA adalah

1. Restriksi antar negara yang tidak valid, asumsi kesamaan fungsi permintaan uang antar negara tidak memperoleh dukungan empiris (Boothe dan Glassman, 1987).

2. Fungsi permintaan dan penawaran uang sendiri bukanlah suatu fungsi yang stabil (Frankel, 1981).

Dengan membatasi pada model OCA dengan IDR sebagai variabel tak bebas, maka terlihat bahwa variabel selisih output nasional (IDUS_GRW) tidak pernah menjadi variabel yang berpengaruh. Dikaitkan dengan alasan yang dikemukakan oleh Frankel (1981), maka pengaruh transaksional dari pendapatan terhadap jumlah uang yang dipegang adalah semakin kecil. Hal ini terjadi dengan adanya peningkatan teknologi, dimana kebutuhan memegang uang secara cash adalah berkurang.

Variabel suku bunga (dan juga ekspektasi suku bunga melalui inflasi) memiliki pengaruh terbesar didalam peran sebagai variabel kontrol. Berbeda dengan ekspektasi umum yang cenderung menganggap bahwa kenaikan suku bunga adalah bersifat apresiatif. Kenaikan suku bunga disini adalah depresiatif. Jika suatu negara menggunakan interest rate targeting dan suku bunga misalnya ditetapkan diatas suku bunga ekuilibrium, maka akan terjadi excess money supply (relatif terhadap mata uang asing) dan sebagai konsekuensinya mata uang ini akan mengalami depresiasi.

Kemampuan variabel OCA ini didalam menjelaskan OCA dengan IDR sebagai variabel terikat tampaknya dapat dihubungkan dengan temuan dari Alesina et al (2002). Analisis mereka terhadap co-movement harga dan output pada berbagai wilayah dunia berkesimpulan bahwa terdapat wilayah yang didefinisikan sebagai area USD.

Dengan demikian sebagai suatu kesimpulan, analisis dan intrepretasi secara ekonomi terhadap kemampuan karakteristik OCA didalam menjelaskan co-movement mata uang ASEAN 4 adalah terbatas. Karakteristik ini hanya "cukup" baik jika digunakan didalam menjelaskan 
model OCA dimana IDR berperan sebagai variabel terikat. Dengan kata lain tampaknya karakteristik OCA terpilih tidak dapat menjadi penjelas umum bagi semua negara ASEAN4. Disini diduga terdapat suatu mekanisme yang berbeda didalam penentuan nilai tukar IDR dibandingkan dengan negara ASEAN4 lainnya.

\section{KESIMPULAN DAN SARAN}

Hasil estimasi menunjukkan OCA ASEAN 4 dalam bentuk yang ideal tampaknya tidak memperoleh dukungan empiris yang kuat. Namun demikian, penelitian yang telah dilakukan tetap memberikan hasil yang menarik diantaranya:

1. Co-movement yang teridentifikasi diantara mata uang ASEAN 4 adalah tidak robust. Dilihat dari perspektif jangka pendek, hipotesis gagal dipenuhi (baik dari segi tanda maupun signifikansi) sedangkan dari jangka panjang, hipotesis juga tidak terpenuhi meskipun hasil estimasi yang diperoleh adalah lebih baik.

2. Kemampuan variabel/karakteristik OCA didalam menjelaskan pergerakan bersama dapat diuraikan sebagai berikut

a. Pada model bivariat dimana IDR adalah variabel terikat (IDR-SGD, IDR-PHP dan IDRTHB), tanda koefisien dan tingkat signifikansi variabel kontrol/karakteristik OCA sendiri (misalnya IDUS_INF) umumnya memiliki tanda yang sesuai dengan hipotesis dan juga signifikan.

b. Pada bivariat yang lain (SGD-PHP, SGD-THB dan PHP-THB), baik variabel kontrol sendiri maupun asing tidak mendukung hipotesis. Dihubungkan dengan tidak signifikannya koefisien error correction (lihat poin 1.b diatas) tampaknya baik co-movement dan OCA tidak teridentifikasi pada model bivariat ini.

3. Keberadaan OCA juga merupakan fenomena global. Hal ini terindikasi dari homogenitas tanda koefisien dan tingkat signifikansi baik persamaan ekuilibrium (yang menunjukkan jangkar USD) dan variabel JPY sebagai mata uang jangkar alternatif diluar USD.

Hasil yang diperoleh dari penelitian ini memiliki beberapa implikasi kebijakan sebagai berikut:

1. Temuan empiris menunjukkan peran Rupiah bersifat asimetris. IDR adalah weak currency yang dikelilingi oleh mata uang lain yang strong currency. Keterkaitan IDR terhadap pergerakan mata uang regional (ASEAN 4) menyarankan kepada pengambil kebijakan untuk menaruh perhatian kepada goncangan yang terjadi dinegara tetangga.

2. Variabel moneter (jumlah uang beredar dan suku bunga) secara empiris berperan didalam penentuan nilai tukar IDR. Dengan demikian otoritas terkait (Bank Indonesia) perlu lebih memperhatikan pengelolaan moneternya agar tidak terjadi goncangan-goncangan terhadap 
nilai tukar. Sebaliknya kebijakan moneter dapat berperan aktif didalam mengelola nilai tukar agar konsisten dengan kestabilan ekonomi.

3. Tidak homogennya faktor-faktor/mekanisme penentuan nilai tukar yang ada diantara negara ASEAN 4 menunjukkan masih dominannya goncangan spesifik-domestik (idiosynchratic shocks) didalam penentuan nilai tukar. Hal ini berimplikasi bahwa orientasi para pembuat kebijakan masih harus condong pada kondisi domestik.

4. Terdapat indikasi peningkatan peran variabel global, khususnya dari negara Jepang. Dengan demikian pengambil kebijakan harus melakukan antisipasi terhadap pergeseran kondisi ekonomi dibeberapa wilayah utama dunia diluar Amerika Serikat, khususnya Jepang. Peran proaktif ini diperlukan agar setiap goncangan dapat diantisipasi sedini mungkin.

Studi ini telah mengungkapkan beberapa temuan empiris penting dan menarik mengenai OCA di ASEAN4. Pengembangan lebih lanjut dapat dilakukan pada dua arah berikut, (1) Penambahan variabel-variabel kontrol/karakteristik OCA yang diduga kuat mempengaruhi seluruh mata uang yang diamati melalui suatu kriteria statistik tertentu dan (2) Penggunaan suatu jangkar berupa komposit dari mata uang utama dunia. 


\section{DAFTAR PUSTAKA}

Alesina, Alberto, Robert J. Barro dan Sylvana Tenreyro, "Optimal Currency Areas", National Bureau Of Economic Research, Working Paper No. 4335, 2002

Baele, Lieven, Ferrando, Annalisa, Hordahl, Peter, Krylova, Elizaveta dan Monnet, Cyril,

"Measuring Financial Integration In The Euro Area, Occassional Papers", European Central Bank, Working Paper No. 14, April 2004.

Bayoumi, Tamim, "A Formal Model Of Optimum Currency Areas", CEPR Discussion Papers No. 968, 1994.

Bayoumi, T and P. Mauro. "The Suitability Of Asean For A Regional Currency Arrangement", International Monetary Fund, Working Paper No. 99/162, December 1999.

Bilson, John F.O "Recent Developments In Monetary Models Of Exchange Rate Determination", IMF Staff Paper No. 26, 1979.

Branson, William dan Healy, Conor N. "Monetary and Exchange Rate Policy Coordination In ASEAN+1", National Bureau Of Economic Research, Working Paper No. 11713, 2005.

Corsetti, G. and Pesenti, Paolo, "Self-Validating Optimum Currency Areas", National Bureau Of Economic Research, Working Paper, No. 8783, 2002.

Corden, W.M." Monetary Integration", Essays In International Finance, International Finance Section No. 93, Princeton University, Dept. Of Economics, 1972.

Dickey, D.A. dan Fuller, W.A., "Distribution Of The Estimators For Autoregressive Time Series With A Unit Root", Journal Of The American Statistical Association, 1979, Vol. 74, hal. 427 431.

Eichengreen, Barry and Bayoumi T," Is Asia An Optimum Currency area? Can It Become One?

Regional, Global and Historical Perspectives On Asian Monetary Relations", Mimeo, University Of California, Berkeley, 1996.

Emerson, M., D. Gros, A. Italianer, J. Pisani-Ferry and H. Reichenbach. "One Market, One Money:

An Evaluation of the Potential Benefits and Costs of Forming an Economic and Monetary Union", New York, Oxford University Press, 1992.

Enders, Walter, Applied Econometric Time Series, John Wiley \& Son, New York, 1995.

Fleming, J. Marcus, "On Exchange Rate Unification", The Economic Journal, 1971, Vol 81, hal 467-88.

Frenkel, J. A., "A Monetary Approach To The Exchange Rate: Doctrinal Aspects and Empirical

Evidence", Scandinavian Journal Of Economics, 1976, 78(2), hal 200-24. 
Frankel, Jeffrey A. "Is Japan Creating A Yen Bloc In East Asia and The Pacific?", National Bureau Of Economic Research, Working Paper No. 4050, April 1992.

Frankel, Jeffrey. A., dan Rose, Andrew K., "Economic Structure and The Decision To Adopt A Common Currency", Background Report, Swedish Government Commission On EMU, Mei 1996.

Frankel, Jeffrey A., dan Rose, Andrew K.,"The Endogeneity Of The Optimum Currency Area", Economic Journal, July 1998, 108(449), hal. 1009-25.

Frankel, Jeffrey A. dan Wei, Shang-Jin. "Trade Blocs and Currency Blocs", National Bureau Of Economic Research, Working Paper No. 4335, April 1993.

Grubel, Herbert G." The Theory Of Optimum Currency Areas", Canadian Journal Of Economics, Mei 1970, hal. 318-324.

Harris, Richard. Using Cointegration Analysis In Econometric Modelling, Harvester Wheatsheaf, Mayland Avenue, 1995.

Hawkins, John and Paul Masson, "Economic Aspects Of Regional Currency areas and The Use Of Foreign Currencies", BIS Working Paper, pp. 4-42, May 2000.

Horvath, Julius., "Optimum Currency Area Theory: A Selective Review", BOFIT Discussion Papers", Vol. 15, 2003.

Johansen, Soren. "Estimation and Hypothesis Testing of Cointegration Vectors in Gaussian Vector Of Autoregressive Models", Econometrica, 1991, Vol. 59, pp. 1551-80.

Kenen, P.B."Theory of Optimum Currency areas: An Eclectic View". dalam R.A. Mundell, dan A.K. Swoboda, eds., Monetary Problems in the International Economy, Chicago, University Of Chicago Press, 1969.

Kim, T-J dan Ryou, J-W, "The Optimum Currency Basket and The Currency Bloc in Asia", Bank Of Korea Economic Papers, Vol 4, No. 1, May, pp. 194-216, 2001.

McKinon, Ronald. "Optimum Currency areas", American Economic Review, 53, September 1963, 717-724.

Mintz, N.N., "Monetary Union and Economic Integration", The Bulletin, New York University, April 1970.

Mongeli, Fransesco P. "New Views On The Optimum Currency Area Theory: What Is EMU Telling US?", ECB Working Paper No. 138, April. 2002.

Mundell, R, , "A Theory Of Optimum Currency Areas", American Economic Review, 1961, hal. 379-96.

Mundel, Robert A. "Uncommon Arguments For Commonc Currencies", dalam H.G. Johnson and A. K. Swoboda,eds., The Economics Of Common Currencies, Allen and Unwin, 1973, hal. 114-32.

Mundell, R, "Prospects for an Asian Currency Area", Journal Of Asian Economics, 2003, no. 14, hal. 1-10. 
Said, S. and David Dickey, "Testing for Unit Roots in Autoregressive-Moving Average Models with Unknown Order", Biometrica, 1984, 71, hal 599-607.

Sims, Christopher, 1980, "Macroeconomics and Reality", Econometrica, 48, hal. 1-49.

Shinji, Takagi,"The Yen and Its Asean Neighbors, 1980-1995: Cooperation Or Competition", National Bureau Of Economic Research, Working Paper No. 5720, 1996.

Warjiyo, Perry, "Materi Kuliah Ekonomi Keuangan Internasional", Program Pasca Sarjana Ilmu Ekonomi, Universitas Indonesia, 2004.

Wilson, Peter." Prospects For Asian Monetary Cooperation After The Asian Financial Crisis: Pipedream or Possible Reality?"National University Of Singapore, Working Paper No. 151, 2002. 